\title{
Multi-colony calibrations of coral Ba/Ca with a contemporaneous in situ seawater barium record
}

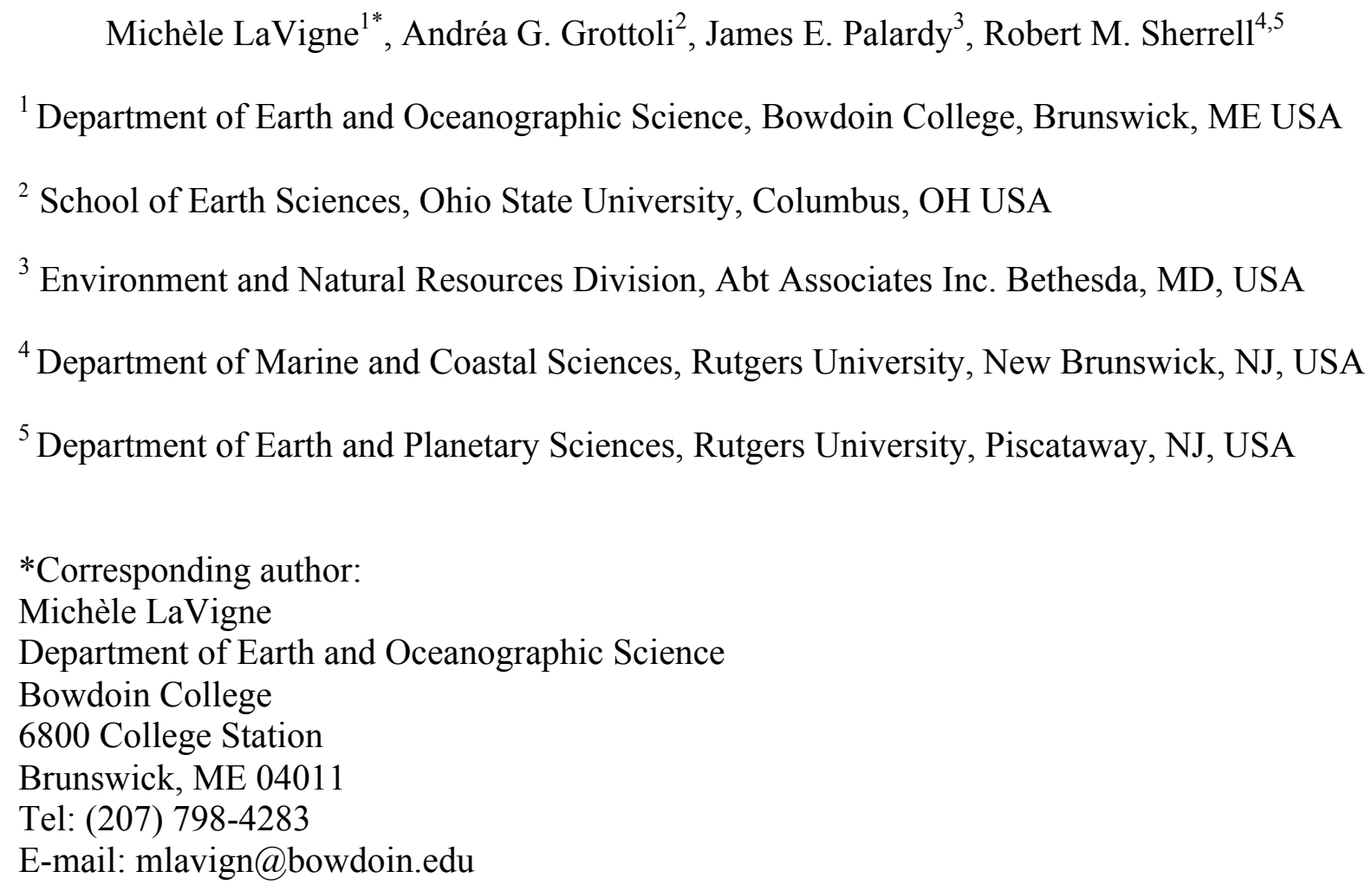




\section{ABSTRACT}

The coral skeleton barium to calcium ratio $(\mathrm{Ba} / \mathrm{Ca}$ coral $)$, a proxy for seawater barium concentrations $\left(\mathrm{Ba}_{S W}\right)$ has been interpreted as a tracer of upwelling based on the characteristic "nutrient like" depth profile of $\mathrm{Ba}_{S W}$. However, in some tropical regions, such as the Gulf of Panamá, substantial influence of terrestrial runoff inputs and differences between the vertical distribution of $\mathrm{Ba}_{S W}$ and that of the major nutrients (nitrate and phosphate) in the upper water column can complicate the interpretation of $\mathrm{Ba} / \mathrm{Ca}$ coral as an upwelled nutrient proxy. In the Gulf of Panamá, contemporaneous $\mathrm{Ba} / \mathrm{Ca} \mathrm{a}_{\text {coral }}$ records from multiple colonies of Porites lobata, Pavona gigantea, and Pavona clavus corals record a nearly two-fold change in surface water $\mathrm{Ba}_{S W}$ as a $20-70 \%$ increase in skeletal $\mathrm{Ba} / \mathrm{Ca}$ with excellent correlation among $\mathrm{Ba} / \mathrm{Ca}$ records from co-located colonies $(\mathrm{r}=0.86-0.99)$. These results provide, for the first time, an absolute calibration of the coral Ba proxy with a contemporaneous $\mathrm{Ba}_{S W}$ record. Compiling the $\mathrm{Ba} / \mathrm{Ca}_{\text {coral }}$ records from three co-located colonies of each species into taxon-specific composite regressions reveals strong statistically significant correlations with the $\mathrm{Ba}_{S W}$ time-series record $(\mathrm{p}<0.001)$. Differences among taxa in regression slope, y-intercept, and average distribution coefficient, as well as a demonstration of the application of the Pavona clavus calibration to a previously published $\mathrm{Ba} / \mathrm{Ca}_{\text {coral }}$ record, emphasize the necessity of using taxon-specific calibrations to reconstruct changes in $\mathrm{Ba}_{S W}$ with accuracy. These results support the application of $\mathrm{Ba} / \mathrm{Ca} \mathrm{a}_{\text {coral }}$ to reconstruct past changes in absolute $\mathrm{Ba}_{S W}$ concentrations, adding an important tool to the collection of geochemical proxies for reconstructing surface ocean biogeochemical processes 
Surface-dwelling reef building corals provide the opportunity to reconstruct continuous centennial scale proxy records of environmental conditions at high (sub-seasonal) resolution. Isotopic and trace element ratios preserved in the banded aragonitic skeleton of surface dwelling coral colonies have been used as proxies for tropical sea surface temperature and salinity (e.g. Beck et al., 1992; Gagan et al., 1994; Nurhati et al., 2011; Carilli et al., 2014). Variations in seawater composition driven by upwelling, coastal runoff, and oceanographic circulation, have also been reconstructed using radiocarbon and trace elemental ratios in tropical coral skeleton $\left(\Delta^{14} \mathrm{C}, \mathrm{Cd} / \mathrm{Ca}, \mathrm{P} / \mathrm{Ca}\right.$, and $\mathrm{Ba} / \mathrm{Ca}$ : e.g. Shen et al., 1987; Lea et al., 1989; Guilderson and Schrag, 1998; Montaggioni et al., 2006; Fleitmann et al., 2007; Matthews et al., 2008; LaVigne et al., 2010; Moyer et al., 2012; Grottoli et al., 2013).

The ratio of barium to calcium in tropical surface coral skeleton $(\mathrm{Ba} / \mathrm{Ca}$ coral $)$ has been shown to track upwelling and/or coastal runoff, depending upon the local sources of barium to surface waters (e.g. Lea et al., 1989; Sinclair and McCulloch, 2004b; Sinclair, 2005; Montaggioni et al., 2006; Fleitmann et al., 2007; Prouty et al., 2010; Maina et al., 2012; Moyer et al., 2012). Dissolved barium is removed from the dissolved phase in the upper water column by the precipitation of micron-scale barite crystals, formed in microenvironments of decaying organic matter and probably by other poorly described mechanisms as well (Dehairs et al., 1980; Bishop, 1988; Ganeshram et al., 2003). Barium is then returned to the dissolved phase in the thermocline and below, such that the resultant vertical concentration profile resembles that of silicate, which is remineralized deeper than nitrate and phosphate. Because of this "nutrient-like" $\mathrm{Ba}_{S W}$ water column profile, $\mathrm{Ba} / \mathrm{Ca}$ in surface corals has been used to reconstruct changes in the upwelling of nutrient-rich thermocline waters (Lea et al., 1989; Fallon et al., 1999; Montaggioni et al., 2006; Allison and Finch, 2007). However, the increase of $\mathrm{Ba}_{S W}$ with depth is relatively subtle compared to the major nutrients nitrate and phosphate. Therefore, terrestrial runoff inputs of Ba to coastal upwelling sites can compromise the interpretation of $\mathrm{Ba} / \mathrm{Ca}$ as an upwelling proxy in some locations. In coastal regions affected by riverine input, skeletal $\mathrm{Ba} / \mathrm{Ca}$ has been shown to track changes in riverine sediment discharge, as barium desorbs from suspended sediment in low salinity estuarine waters, increasing $\mathrm{Ba}_{S W}$ and thus, skeletal $\mathrm{Ba} / \mathrm{Ca}$ coral $(\mathrm{Li}$ and Chan, 1979; Alibert et al., 2003; McCulloch et al., 2003; Sinclair and McCulloch, 2004a; Fleitmann et al., 2007; Prouty et al., 2008; Carriquiry and Horta-Puga, 2010; Prouty et al., 2010; HortaPuga and Carriquiry, 2012; Maina et al., 2012; Moyer et al., 2012; Mallela et al., 2013).

While the previous work discussed above has correlated $\mathrm{Ba} / \mathrm{Ca}_{\text {coral }}$ variations to the occurrence of upwelling and terrestrial runoff events, the lack of a direct calibration of $\mathrm{Ba} / \mathrm{Ca}_{\text {coral }}$ against $\mathrm{Ba}_{S W}$ has limited interpretations to relative changes in $\mathrm{Ba} / \mathrm{Ca}_{\text {coral }}$ rather than quantitative reconstructions of absolute $\mathrm{Ba}_{S W}$. Quantitative estimates of $\mathrm{Ba}_{S W}$ concentration from modern high-resolution coral records would allow for modeling seasonal-centennial variations in upwelling depth, riverine flux, or removal via primary production and barite formation (Lea et al., 1989).

Previous studies of foraminifera, deep sea corals, and inorganic precipitation of calcium 
94

carbonate have demonstrated that barium incorporates into calcite and aragonite in proportion to the $\mathrm{Ba} / \mathrm{Ca}$ ratio of seawater (Kitano et al., 1971; Lea and Boyle, 1989; Lea et al., 1989; Lea and Spero, 1992; Dietzel et al., 2004; Anagnostou et al., 2011; Hönisch et al., 2011; LaVigne et al., 2011). Based on the assumption that cations in general incorporate into carbonates via inorganic substitution for calcium, distribution coefficients (D) have been used to relate the composition of these carbonates to that of the solution from which they precipitated (Morse and Bender, 1990).

$\mathrm{D}_{B a}=\left(\mathrm{Ba} / \mathrm{Ca}_{C a C O 3}\right) /\left(\mathrm{Ba} / \mathrm{Ca}_{S W}\right)$

(Eq. 1)

Values for $\mathrm{D}_{B a}$ have been found to be roughly similar for various species of aragonitic surface-dwelling and deep sea corals as well as inorganic aragonite ( 1.2-1.4), suggesting that barium incorporation occurs via relatively simple ionic substition and is not affected by the presence of symbionts or other vital effects (Lea and Boyle, 1989; Lea et al., 1989; Lea and Spero, 1992; Alibert et al., 2003; Dietzel et al., 2004; Anagnostou et al., 2011; Hönisch et al., 2011; LaVigne et al., 2011). Values of $\mathrm{D}_{B a}$ that are estimated from coral analysis coupled to regional estimates of seawater barium concentrations, disconnected in time or space from the coral growth location, may lead to inaccuracies in the reconstruction of absolute $\mathrm{Ba}_{S W}$ concentration in the past. For example, acknowledging the lack of a direct calibration, Lea et al. (1989) used $\mathrm{D}_{B a}=1.3$, estimated from mean Ba/Ca measured in Bermuda Montastrea annularis and Diploria labyrinthiformis corals and $\mathrm{Ba}_{S W}$ from a single GEOSECS station located $1,700 \mathrm{~km}$ northeast of Bermuda to reconstruct $\mathrm{Ba}_{S W}$ variations in Galápagos from a Pavona clavus $\mathrm{Ba} / \mathrm{Ca}_{\text {coral }}$ record. Little progress in refining measurements of $\mathrm{D}_{B a}$ or exploring taxonomic or other dependencies of the $\mathrm{Ba} / \mathrm{Ca}$ proxy has been made in the ensuing 25 years.

Recent work on previously established hermatypic coral proxies $\left(\delta^{18} \mathrm{O}, \mathrm{Sr} / \mathrm{Ca}\right.$, and $\left.\mathrm{Cd} / \mathrm{Ca}\right)$ has shown that averaged multi-colony records can yield more accurate seawater reconstructions (DeLong et al., 2007; Goodkin et al., 2007; Linsley et al., 2008; Matthews et al., 2008; DeLong et al., 2011; DeLong et al., 2013; Grottoli et al., 2013). Therefore, the natural variability in $\mathrm{Ba} / \mathrm{Ca}_{\text {coral }}$ records among co-located colonies and taxa must be assessed to evaluate the reproducibility and accuracy of downcore $\mathrm{Ba}_{S W}$ reconstructions.

A field-based study carried out in the Gulf of Panamá in 2003 led to the first direct calibration of two trace elemental upwelling tracers in surface-dwelling corals: $\mathrm{Cd} / \mathrm{Ca}$ and P/Ca (Matthews et al., 2008; LaVigne et al., 2010; Grottoli et al., 2013). This work revealed good intercolony reproducibility for $\mathrm{P} / \mathrm{Ca}$ in Pavona gigantea and Porites lobata corals, however, $\mathrm{Cd}$ variability among co-located colonies suggests that $\mathrm{Cd}$ records derived from a single coral may not yield reliable upwelling reconstructions (Matthews et al., 2008; Grottoli et al., 2013). In this study, we take advantage of this unique set of seawater and coral samples to develop the first multi-colony calibrations for $\mathrm{Ba} / \mathrm{Ca}_{\text {coral }}$ using a contemporaneous $\mathrm{Ba} / \mathrm{Ca}_{S W}$ record. 


\subsection{Samples}

\section{METHODS}

An archived set of replicate coral colonies and a time series of in situ seawater samples from a previous study in the Gulf of Panamá were analyzed to assess inter-colony $\mathrm{Ba} / \mathrm{Ca}$ coral reproducibility (Matthews et al., 2006; Matthews et al., 2008; LaVigne et al., 2010; Grottoli et al., 2013). Full field study details are available in Matthews et al. (2008). In short, we analyzed nine coral colonies (three Porites lobata, three Pavona clavus, and three Pavona gigantea) reared at the same site (Isla Contadora, $1 \mathrm{~m}$ depth below mean low tide) with corresponding in situ seawater samples collected every three days through both upwelling and non-upwelling intervals. At the start of the experiment, all colony fragments were collected regionally from $\sim 1-4$ m depth, stained with Alizarin Red, and cemented to the reef at $1 \mathrm{~m}$ depth for the duration of the experiment. The $P$. lobata and P. gigantea colonies were collected within $\sim 15 \mathrm{~m}$ of the study site. Because of the lack of individuals growing near the study site, the $P$. clavus colonies used in this experiment were transplanted from the North coast of Isla Contadora to the South coast study site (a distance of $1.1 \mathrm{~km}$ ). Sea surface temperature (SST), salinity, and light intensity were measured from January to July 2003 at Isla Contadora with seawater samples collected at $1 \mathrm{~m}$ depth every three days, filtered, and acidified following trace metal clean procedures (Field et al., 2007; Matthews et al., 2008). The corals were stained in situ with Alizarin Red on 31 January 2003, 15 April 2003, and 13 July 2003 (marking the beginning, middle, and end of the six-month study period) and harvested in February 2004. Skeletal extension was measured between each pair of stain lines using a micrometer to calculate the skeletal extension rates (Fig. S1).

The skeletal $\mathrm{Ba} / \mathrm{Ca}$ data shown here were collected during the ICP-MS analysis of these coral samples for $\mathrm{P} / \mathrm{Ca}$; the latter results were published previously (LaVigne et al., 2010). Full analytical details can be found in LaVigne et al. (2010). In brief, contiguous powdered samples (1-2 mg) were extracted from each colony, resulting in $\sim 2-3$ week temporal resolution over the period investigated for all samples except PG3, which resulted in $\sim 6$ week resolution. The powders were collected near the surface organic tissue layer, thus an oxidative/reductive solution cleaning technique was performed as a precaution on all samples to remove any residual non-skeletal matrix organic matter that could overprint the trace element signals incorporated into the aragonite matrix (Shen and Boyle, 1988).

These skeletal transects covered $\sim 1$ year of growth: the $\sim 6$ months prior to the study as well as the 6 month study period following transplantation and initiation of the seawater sampling. Only $\mathrm{Ba} / \mathrm{Ca}_{\text {coral }}$ data measured at or between the stain lines are reported in Fig. S1. Samples collected below (earlier than) the first stain line were used solely for $\mathrm{Sr} / \mathrm{Ca}-\mathrm{SST}$ age model reconciliation purposes (described below: Section 2.3). The $\mathrm{Ba} / \mathrm{Ca}_{\text {coral }}$ data collected below the first stain line (reported in Fig. S1) were excluded from the $\mathrm{Ba} / \mathrm{Ca}$ calibrations since this skeletal material is likely a combination of carbonate deposited prior to the $\mathrm{Ba}_{s w}$ sampling interval when corals were growing at different locations and skeletal material thickened during the study period. It is probable that some backfilling due to thickening of the skeleton may have affected all of the Gulf of Panamá coral skeleton used in this study. Although the 
samples below the last stain line likely included some material deposited after the study

183 period, this would have occurred during late summer when all colonies were co-located and 184 stable stratified conditions typically persist for several months.

\subsection{Analyses}

All sample preparation and high resolution inductively couple plasma mass spectrometry (HR-ICP-MS) and inductively couple plasma optical emission spectrometry (ICP-OES) analyses followed standard laboratory protocols for trace element analysis under Class 100 conditions. All solutions were made with ultrapure reagents (OPTIMA grade, Fisher Scientific) and Milli-Q (18.2 M $\Omega$-cm, Millipore, MA, USA) water unless otherwise noted.

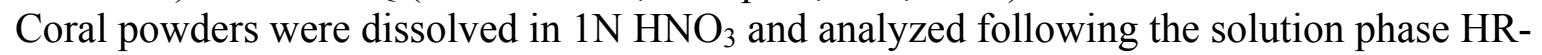
ICP-MS method described in LaVigne et al. (2010). In order to minimize differential plasma matrix effects between samples during analysis (de Villiers et al., 1994; Rosenthal et al., 1999), the dissolution volume of each sample was tailored to achieve $4 \mathrm{mM} \mathrm{Ca}$ and 1.0$1.5 \mathrm{mM} \mathrm{Ca}$ in $3 \% \mathrm{HNO}_{3}$ for HR-ICP-MS and ICP-OES measurement, respectively. The $\mathrm{Ba} / \mathrm{Ca}$ measurements were carried out on an Element-XR (Thermo Scientific, Bremen, Germany) HR-ICP-MS equipped with a quartz spray chamber and a PFA MicroFlow nebulizer. The instrument was operated in low-resolution mode for analyzing barium and calcium using isotopes selected to maximize natural abundance and minimize polyatomic interferences $\left({ }^{138} \mathrm{Ba}\right.$ and $\left.{ }^{48} \mathrm{Ca}\right)$. The average analytical reproducibility for $\mathrm{Ba} / \mathrm{Ca}$ measurements was $\pm 5.8 \%$ based on replicate runs of an in-house matrix-matched coral consistency standard $(9.9 \pm 0.58 \mu \mathrm{mol} / \mathrm{mol} ; 1 \mathrm{SD} ; \mathrm{n}=24)$ and duplicate dilutions of samples (average deviation from mean for $\mathrm{n}=9$ pairs of duplicates $=0.14 \mu \mathrm{mol} / \mathrm{mol}$ or $2.5 \%$ average deviation from mean). The $\mathrm{Ba}$ and $\mathrm{Ca}$ blanks subtracted from sample signals were $<0.1 \%$ and $<0.02 \%$ respectively. Six apparent outliers with high $\mathrm{Ba} / \mathrm{Ca}$ values were selected from the data for reanalysis in a separate run. The data from four of the six re-analyzed samples did not agree with the initial $\mathrm{Ba} / \mathrm{Ca}$ measurements (within uncertainty), therefore, these samples were excluded from further analysis. In addition, two outliers (PG1 7-9mm and PL1 17$18 \mathrm{~mm}$ ) were excluded from data analysis because of anomalously high $\mathrm{Ba} / \mathrm{Ca}$ values compared against overlapping and/or neighboring data points and were likely a result of contamination or inefficient removal of organic matter during cleaning of those samples.

The filtered seawater samples were diluted by a factor of ten and analyzed for dissolved barium $\left(\mathrm{Ba}_{S W}\right)$ using a HR-ICP-MS method described by Field et al. (2007). The average analytical reproducibility for $\mathrm{Ba}_{S W}$ measurements was $\sim 2 \%$ based on the analysis of replicate dilutions of 10 samples (average deviation about mean $=1.173 \mathrm{nmol} / \mathrm{kg} 1 \mathrm{SD} ; \mathrm{n}=10$ duplicate pairs). Repeat measurements of barium in a NASS-5 seawater standard reference material agree within the uncertainty of previous measurements of barium in this standard $(5.33 \pm 0.02 \mu \mathrm{g} / \mathrm{L} ; 1 \mathrm{SD} ; \mathrm{n}=6$; National Research Council Canada; Field et al., 2007).

The Sr/Ca data used in this study for the Porites lobata and Pavona gigantea samples were generated using ICP-OES as described in LaVigne et al. (2010). The Pavona clavus corals were analyzed for $\mathrm{Sr} / \mathrm{Ca}$ at Bowdoin College following the method described by (Schrag, 1999) using a MPX Vista ICP-OES (Varian, Inc., CA, USA) equipped with a cyclonic quartz 
spray chamber and a PFA microflow $100(100 \mu \mathrm{L} / \mathrm{min})$ nebulizer (Elemental Scientific, Inc.,

$\mathrm{NE}, \mathrm{USA}$ ). The emission line ratio calculated for data interpretation was $\mathrm{Sr}_{216} / \mathrm{Ca}_{315}$, which was determined to be most accurate and precise based on replicate analyses of an in-house matrix-matched coral standard and an otolith certified reference material for trace metals (FEBS-1; National Research Council Canada). The mean of repeat measurements of $\mathrm{Sr} / \mathrm{Ca}$ in FEBS-1 $(2.270 \pm 0.0175 \mathrm{mmol} / \mathrm{mol} ; 1 \mathrm{SD} ; 0.77 \% \mathrm{RSD} ; \mathrm{n}=12)$ agreed within the uncertainty of previously published measurements $(2.33 \pm 0.14 \mathrm{mmol} / \mathrm{mol}$ : Robinson et al., $2009)$ and was accurate within $2 \%$ of the certified range of the standard $(2.45 \pm 0.13$ $\mathrm{mmol} / \mathrm{mol}$ ). Reproducibility for $\mathrm{Sr} / \mathrm{Ca}$ determinations of an in-house consistency standard ( $\mathrm{n}$ $=15$ ) and replicate dilutions of samples ( $\mathrm{n}=8$ pairs of duplicates) over three days of analyses was $0.7 \%$ RSD.

\subsection{Age Model}

Smoothing relative to short-term environmental variations was observed in the skeletal $\mathrm{Ba} / \mathrm{Ca}$ records of all three coral taxa, similar to that seen in the $\mathrm{P} / \mathrm{Ca}$ and $\mathrm{Cd} / \mathrm{Ca}$ records from these samples (Matthews, 2007; LaVigne et al., 2010; Grottoli et al., 2013). This smoothing of geochemical signals most likely results from a combination of the $\sim 1 \mathrm{~mm}(\sim 2-3$ week$)$ sampling resolution as well as skeletal thickening caused by calcification throughout the coral tissue layer (Barnes and Lough, 1993; Taylor et al., 1993; Barnes et al., 1995). Skeletal thickening has been found to result in a "bio-smoothing" of $\mathrm{Sr} / \mathrm{Ca}$ records within the tissue layer during skeletogenesis in Porites corals (Gagan et al., 2012). We assume that thickening affected $\mathrm{Sr} / \mathrm{Ca}, \mathrm{Ba} / \mathrm{Ca}$, and $\mathrm{P} / \mathrm{Ca}$ equally, and thus, applied the same $\mathrm{Sr} / \mathrm{Ca}$-derived age model used for the $\mathrm{P} / \mathrm{Ca}$ data to the corresponding $\mathrm{Ba} / \mathrm{Ca}$ measurements from the Porites lobata and Pavona gigantea coral samples (LaVigne et al., 2010). Because the Pavona clavus corals were not analyzed for $\mathrm{Sr} / \mathrm{Ca}$ in the previous study, we followed the same approach to derive age models based on the new Pavona clavus $\mathrm{Sr} / \mathrm{Ca}$ data.

In brief, following the method of (Swart et al., 2002), we used a Sr/Ca - SST chronology adjustment as an independent method of accounting for the timing offset between the incorporated coral records and in situ seawater records. The stain-line derived chronology was adjusted to align the $\mathrm{Sr} / \mathrm{Ca}$ coral record with the in situ seawater SST measurements. Dates were assigned to three inflection points in the coralline $\mathrm{Sr} / \mathrm{Ca}$ records to adjust the chronology of each colony so that $\mathrm{Ba} / \mathrm{Ca}$ calibrations could be calculated appropriately (Fig. S2). Low-resolution evenly spaced sampling between the stain lines of corals with uneven growth rates and differences between stain-derived and $\mathrm{Sr} / \mathrm{Ca}$ age models resulted in relatively short $\mathrm{Ba} / \mathrm{Ca}$ records for some corals (e.g. PG1 and PG2). Unequal representation of seasons in coral records with variable growth rates has also been observed in isotopic records from the Galápagos upwelling region (Wellington et al., 1996). The skeletal $\mathrm{Sr} / \mathrm{Ca}-$ SST age model adjustment described above accounts only for geochemical signal stretching caused by thickening. In addition to stretching the environmental signal, we also expected the skeletal thickening process and sampling integration to produce smoothed skeletal records relative to the high-resolution seawater signal (Cohen and Thorrold, 2007; Gagan et al., 2012). Therefore, to compensate for this effect, the $\mathrm{Ba}_{S W}$ data were smoothed using a 2-7 point moving average before re-sampling at the resolution of the coral data using the linear 
integration interpolation function of the AnalySeries program, as was performed for previous $\mathrm{P} / \mathrm{Ca}-\mathrm{PO}_{4 S W}$ calibrations (Paillard et al., 1996; LaVigne et al., 2010). We identified the appropriate $\mathrm{Ba}_{S W}$ smoothing window to account for "bio-smoothing" in each colony (2-7 points of the seawater record: equivalent to $\sim 1-3$ weeks) by optimizing the coral $\mathrm{Ba} / \mathrm{Ca}$ smoothed $\mathrm{Ba}_{S W}$ correlation coefficient (LaVigne et al., 2010). This degree of smoothing occurs on a shorter timescale than the "bio-smoothing" found for $\mathrm{Sr} / \mathrm{Ca}$ signals in Porites corals by Gagan et al. (2012: 3-12 months). Although Gagan et al. (2012) found that 3-12 month smoothing windows can attenuate environmental signals by 2-64\% in Porites corals, we did not observe any attenuation of the seasonal $\mathrm{Ba}_{S W}$ signal in the $\mathrm{Ba} / \mathrm{Ca}$ coral records using the 1-3 week smoothing window that was found to be optimal for our samples. The similar range of smoothing windows required for all three coral taxa suggests that the signal smoothing observed for Porites by Gagan et al. (2012) also occurs in the Pavona species studied here.

\subsection{Statistical Analysis}

Pearson correlation coefficients ( $\mathrm{r}$ ) were used to determine the degree of linear correlation between coral $\mathrm{Ba} / \mathrm{Ca}$ and $\mathrm{Ba}_{S W}$ for each colony analyzed. P-values below 0.05 were considered statistically significant unless otherwise noted. Calibration slopes and yintercepts were calculated to model the relationship between $\mathrm{Ba} / \mathrm{Ca}$ and $\mathrm{Ba}_{S W}$ using the Deming regression method, which accounts for uncertainties in both $\mathrm{x}$ and $\mathrm{y}$ variables. Statistical analyses were performed using Prism 6 software for Mac (Version 6.0d, October 2013, GraphPad Software, Inc.) and R (R Core Team, 2012).

\section{RESULTS AND DISCUSSION}

\subsection{Dissolved barium variability in the Gulf of Panamá}

The in-situ SST, sea surface salinity (SSS), Cd $\mathrm{d}_{S W}$, and soluble reactive phosphate $\left(\mathrm{PO}_{4}\right)$ data collected throughout the study period have been used to calibrate $\mathrm{Cd} / \mathrm{Ca}$ and $\mathrm{P} / \mathrm{Ca}$ proxies in surface-dwelling corals (Matthews et al., 2008; LaVigne et al., 2010; Grottoli et al., 2013). New barium data measured in these seawater and coral samples now allow us to test the characteristics of the $\mathrm{Ba} / \mathrm{Ca}_{\text {coral }}$ proxy. In addition, the Gulf of Panamá seawater data provide insight into the drivers of surface nutrient and trace element variability that could affect how these proxies are interpreted in corals from similar coastal upwelling regimes (Fig. 1). Early in the year (January-April), the ITCZ is located south of Panamá such that northerly winds promote upwelling and dry atmospheric conditions in the Gulf. Summer months (MayDecember), however, are characterized by low atmospheric pressure, increased precipitation, and warm stratified conditions resulting from the more northerly position of the ITCZ (Forsbergh, 1969; D'Croz et al., 1991). The SST and SSS data collected in 2003 demonstrate this transition from the pulsed cool SST upwelling events prevailing in the relatively dry and higher salinity months of late Winter/early Spring to the warm stratified lower-salinity conditions common in the rainy summer season (Forsbergh, 1969; D'Croz et al., 1991; Fig. 1). The $\mathrm{Cd}_{S W}, \mathrm{PO}_{4}$, and $\mathrm{Ba}_{S W}$ time series data collected through this transition demonstrate 
the unique temporal behavior for each of these biogeochemically relevant properties in surface waters of a coastal upwelling site (Fig. 1).

Skeletal barium, cadmium, and phosphorus have all been considered as proxies for winddriven upwelling in surface-dwelling corals based upon the general enrichment of these macro and micro nutrients with increasing depth in the ocean (e.g. Shen et al., 1987; Lea et al., 1989; Matthews et al., 2008; LaVigne et al., 2010; Grottoli et al., 2013). However, our data indicate that surface concentrations of these elements do not all vary concurrently with upwelling on sub-annual (weekly-monthly) timescales in the Gulf of Panamá (Fig. 1). Surface phosphate bears the closest resemblance to the pulsed upwelling signal with concentrations increasing during cool upwelling pulses in late Winter/early Spring and decreasing into the non-upwelling season. Dissolved cadmium, however, peaks later in the year ( $\sim$ mid-summer), previously suggested to be a result of biological uptake competing with upwelling supply during the highly productive Spring upwelling season, thus complicating the use of $\mathrm{Cd} / \mathrm{Ca}$ as a direct proxy for upwelling (Matthews et al., 2008; Grottoli et al., 2013). Barium, which has been used as an upwelling tracer in other eastern equatorial Pacific corals, demonstrates a seasonal trend opposite to that of phosphate in Gulf of Panamá surface waters: increasing from winter to summer, with minimal apparent influence of the upwelling events that punctuate the SST and $\mathrm{PO}_{4}$ records. Instead, $\mathrm{Ba}_{S W}$ has a strong inverse correlation with SSS ( $r=-0.92 ; p<0.0001 ;$ Fig. 2), indicating that seasonal barium variability at this location is driven more by terrestrial runoff supply to surface waters during the rainy summer season than by upwelling supply from subsurface waters in winter (Fig. 1). Extrapolating our Panamá regression of $\mathrm{Ba}_{S W}$ to SSS $\left(\mathrm{Ba}_{S W}(\mathrm{nmol} / \mathrm{kg})=-3.88 * \mathrm{SSS}+174.96\right)$ back to the approximate salinity of peak dissolved barium concentrations in estuaries ( $\sim 4)$ yields a dissolved barium concentration of $\sim 160 \mathrm{nmol} / \mathrm{kg}$, which is in agreement with an average of peak barium concentrations in the Zaire, Amazon, Ganges, Chesapeake, and Delaware estuaries (salinity 4 and $164 \mathrm{nmol} / \mathrm{kg}$ dissolved barium; Coffey et al., 1997). Freshwater flux to the Gulf during the high precipitation season likely causes barium to desorb from river-borne suspended particulate matter during transport from fresh to saline waters (Li and Chan, 1979; Coffey et al., 1997). Runoff into Panamá Bight is typically greatest in May-June and lowest in Feb-March (Forsbergh, 1969; Fig. 1). The sharp increase in $\mathrm{Ba}_{S W}$ following a minimum in $\sim$ Feb-March corresponds to this timing (Fig. 1). This suggests that instead of acting as a tracer of upwelling at this site, $\mathrm{Ba} / \mathrm{Ca}$ coral likely serves as a proxy for terrestrial runoff even in this strong upwelling region. Taken together, these data show that proxies typically considered to be tracers of upwelling in corals (e.g. $\mathrm{Cd} / \mathrm{Ca}, \mathrm{P} / \mathrm{Ca}$, $\mathrm{Ba} / \mathrm{Ca}$ ) must be carefully interpreted in light of local processes affecting surface water biogeochemistry. Conversely, studies using a well-calibrated multi-proxy approach could take full advantage of the variety of processes affecting these tracers to provide a more complete picture of the complex biogeochemical variations that may occur in such regions.

\section{2. $\mathrm{Ba} / \mathbf{C a}_{\text {coral }}$ calibration against in situ $\mathrm{Ba}_{S W}$}

\subsubsection{Intercolony Ba/Ca Reproducibility}

The unique set of replicate coral and contemporaneous in situ seawater samples collected 
from Isla Contadora, Panamá allows us to assess natural $\mathrm{Ba} / \mathrm{Ca}$ variability among co-located coral colonies and taxa. All nine Porites lobata, Pavona gigantea, and Pavona clavus colonies grew through the mid-year transition from dry to rainy conditions in 2003, and recorded the $\sim 35 \mathrm{nmol} / \mathrm{kg} \mathrm{Ba} S W$ increase as a $\sim 1-4 \mu \mathrm{mol} / \mathrm{mol}(20-70 \%)$ rise in skeletal $\mathrm{Ba} / \mathrm{Ca}$ (Fig. S1, Fig. 3). A similar degree of $\mathrm{Ba} / \mathrm{Ca}$ increase has been observed during flood events in Great Barrier Reef Porites corals (McCulloch et al., 2003). The reproducibility among the replicate colony records plotted in Figure 3 was evaluated by calculating correlation coefficients (r) between their $\mathrm{Ba} / \mathrm{Ca}_{\text {coral }}$ records within each taxon. Each colony record was re-sampled at the timescale of each of the other corals using AnalySeries to construct common timescales such that correlation coefficients and p-values could be calculated. Within each taxon, we find excellent agreement between members of each pair of the replicate colony $\mathrm{Ba} / \mathrm{Ca}_{\text {coral }}$ records ( $\mathrm{r}=0.86-0.99$; Table 1$)$. The correlation coefficients for the Pavona gigantea replicate corals and one of the Pavona clavus coral pairs, however, were not statistically significant ( $>0.05$; Table 1 ). This is likely a result of the lower growth rates of the Pavona gigantea records resulting in lower resolution records and thus, fewer data points as compared to the other taxa (Table 1, Fig. 3). The excellent agreement for the Porites lobata and Pavona clavus corals, however, demonstrates a high level of intercolony reproducibility among the $\mathrm{Ba} / \mathrm{Ca}$ coral records. The $\mathrm{Ba} / \mathrm{Ca}$ increase occurred at least 5-10 $\mathrm{mm}$ below the tissue layer in each coral and based on the agreement among colonies, the $\mathrm{Ba} / \mathrm{Ca}$ increases measured are not a result of inefficient cleaning of organic tissue. Longer or higher resolution records from the Pavona gigantea corals are required to evaluate the significance of the apparent agreement among the co-located Pavona gigantea colonies studied here (Fig. 3; Table 1). Applying the $\mathrm{Sr} / \mathrm{Ca}$-derived age models to the high-resolution $\mathrm{Ba} / \mathrm{Ca}_{\text {coral }}$ data (Section 2.3) allowed us to perform linear regressions against $\mathrm{Ba}$ sW for each of the nine corals.

\subsubsection{Taxon-Specific Regressions}

With $\mathrm{Ba} / \mathrm{Ca}_{\text {coral }}$ data from multiple well-dated co-located coral colonies and a high-resolution contemporaneous in situ $\mathrm{Ba}_{S W}$ record, we can generate colony-specific $\mathrm{Ba} / \mathrm{Ca}$ regressions and begin to evaluate inter-colony calibration reproducibility. Pearson correlation coefficients reveal a linear relationship between $\mathrm{Ba} / \mathrm{Ca}_{\text {coral }}$ and $\mathrm{Ba}_{S W}$ for all nine coral colonies $(\mathrm{r}=0.70$ 0.99 ), five of which are statistically significant ( $<<0.04$; Table S1). Regressions of $\mathrm{Ba} / \mathrm{Ca}_{\text {coral }}$ against the re-sampled $\mathrm{Ba} S W$ record were used to construct individual calibration equations for each of the nine colonies (Fig. 4; Table S1).

Within each genus, the individual colony regressions agree within the uncertainty of their calculated slopes and y-intercepts except for two colonies (PG3, which consists of only three data points and is not statistically significant, and PC1; Table S1). The lack of statistical significance for colonies PL1, PG1, and PC2 is likely a result of two factors influencing these data sets ( $p=0.09-0.12$; Table S1). First, low sampling resolution and growth rates for some colonies result in very few $\mathrm{Ba} / \mathrm{Ca}$ measurements within the study period available for the regression calculations (e.g. PG3 $n=3$ ). Second, the coral data from several colonies do not span a very large dynamic range in $\mathrm{Ba}_{S w}$. This can occur as a result of evenly spaced 
406

407

408

409

410

411

412

413

414

415

416

417

418

419

420

421

422

423

424

425

426

427

428

429

430

431

432

433

434

435

436

437

438

439

440

441

442

443

444

445

446

447

448

449

450

sampling of corals that do not have constant growth rates (Wellington et al., 1996). For example, for colonies PG1, PG3, and PC2, most of the data points sampled from the coral fall in the early stable portion of the $\mathrm{Ba}_{S W}$ record (Fig. 3, Fig. 4). Because the samples were drilled by hand at $\sim 1 \mathrm{~mm}$ resolution on corals with varying growth rates, the sampling resolution and distribution of samples through the study period can vary from coral to coral. Compared to other seawater parameters (for example, phosphate), the $\mathrm{Ba}_{S W}$ transition occurs later in the study period (May 2003) during a period when fewer samples were extracted from the corals (Fig. 3) . Thus, even though there is overlap between colony regression standard errors, the uncertainty associated with reconstructed $\mathrm{Ba}_{S W}$ measurements made with these individual colony-specific regressions would be too large for reliable proxy reconstructions (17-200\% or $\pm 7-80 \mathrm{nmol} / \mathrm{kg} \mathrm{Ba} S W$ for the range of $\mathrm{Ba}_{S W}$ values studied here: $\sim 40-70 \mathrm{nmol} / \mathrm{kg}$ ). The overall intercolony agreement is good among the $\mathrm{Ba} / \mathrm{Ca}$ coral records themselves, however additional work is needed to construct and compare higher-resolution calibrations from individual colonies.

Recently, multi-colony calibrations and reconstructions have been found to improve the accuracy and precision of coralline paleoceanographic reconstructions (e.g. DeLong et al., 2007; Goodkin et al., 2007; Linsley et al., 2008; Matthews et al., 2008; Pfeiffer et al., 2009; DeLong et al., 2013; Grottoli et al., 2013; DeLong et al., 2014; Williams et al., 2014). Given the intercolony reproducibility in the Gulf of Panama $\mathrm{Ba} / \mathrm{Ca}_{\text {coral }}$ records and broad overlap in the standard error of the individual regression slopes and y-intercepts, we pooled the data from the three replicate colonies for each taxon studied into the following composite regressions (Fig. 5; Table S1).

$$
\begin{aligned}
& \mathrm{Ba} / \mathrm{Ca}_{\text {Porites lobata }}(\mu \mathrm{mol} / \mathrm{mol})=0.14 \pm 0.02 *\left(\mathrm{Ba}_{S W} \mathrm{nmol} / \mathrm{kg}\right)-0.8 \pm 1.0 \\
& \mathrm{Ba} / \mathrm{Ca}_{\text {Pavona gigantea }}(\mu \mathrm{mol} / \mathrm{mol})=0.06 \pm 0.01 *\left(\mathrm{Ba}_{S W} \mathrm{nmol} / \mathrm{kg}\right)+3.0 \pm 0.6 \\
& \mathrm{Ba} / \mathrm{Ca}_{\text {Pavona clavus }}(\mu \mathrm{mol} / \mathrm{mol})=0.09 \pm 0.015 *\left(\mathrm{Ba}_{S W} \mathrm{nmol} / \mathrm{kg}\right)+0.9 \pm 0.7
\end{aligned}
$$

All multi-colony data sets reveal strong statistically significant relationships between $\mathrm{Ba} / \mathrm{Ca}_{\text {coral }}$ and $\mathrm{Ba}_{S W}$ for the three taxa studied $(\mathrm{r}=0.8 ; \mathrm{p}<0.001 ;$ Fig. 5). Using constructed linear mixed effects models in $\mathrm{R}$ using the lme4 package (R Core Team, 2012; Bates et al., 2012; Winter, 2013) to test for colony-specific effects, we found slopes and y-intercepts that agree within the uncertainty of the Deming regression for each taxon. In the mixed effect model analyses, we treated the relationship between $\mathrm{Ba}_{S W}$ and $\mathrm{Ba} / \mathrm{Ca}_{\text {coral }}$ as a fixed effect, and colony-specific intercepts as a random effect. The uncertainty in absolute $\mathrm{Ba}_{S W}$ values reconstructed using the composite calibrations (Eq. 2 - 4) is lower than that using the individual colony regressions ( $\pm \sim 14-27 \mathrm{nmol} / \mathrm{kg}$ vs. up to $\pm 80 \mathrm{nmol} / \mathrm{kg} \mathrm{Ba} S W$ for the range of $\mathrm{Ba}_{S W}$ values studied here: $\sim 40-70 \mathrm{nmol} / \mathrm{kg}$ ), but suggests that the calibrations would benefit from further refinement. The Porites lobata and Pavona clavus slopes and y-intercepts from the individual colony regressions agree within the uncertainty of the composite calibration equation except for one colony (PC1). The PC1 regression appears to be driven by a single data point at the high end of the regression (Fig. 4). The individual Pavona gigantea colony 
slopes and y-intercepts, however, do not all agree with the composite equation, which is likely a result of the narrow dynamic range covered by these records as discussed above.

453 Because the composite regressions reveal more robust relationships between $\mathrm{Ba} / \mathrm{Ca}_{\text {coral }}$ and

$454 \mathrm{Ba}_{S W}$ compared to the individual colony regressions, multi-colony reconstructions of $\mathrm{Ba}_{S W}$ would likely yield more precise results than single colony records. Future work with longer records covering a range of measured $\mathrm{Ba}_{S W}$ would allow for a more sophisticated statistical analysis of the inter-colony reproducibility of the $\mathrm{Ba} / \mathrm{Ca}$ calibrations, as has been accomplished recently for $\mathrm{Sr} / \mathrm{Ca}$ and $\mathrm{Mg} / \mathrm{Ca}$ in other coral archives (e.g. DeLong et al., 2007; Goodkin et al., 2007; Pfeiffer et al., 2009; DeLong et al., 2011; DeLong et al., 2013; Williams et al., 2014).

\subsection{3: Incorporation of barium and implications for reconstructions.}

Distribution coefficients $\left(\mathrm{D}_{B a}\right)$ were calculated for each coral by dividing the mean $\mathrm{Ba} / \mathrm{Ca}$ coral value for each colony by the mean of the $\mathrm{Ba} / \mathrm{Ca}_{S W}$ values calculated for each colony as described below (Eqn. 1; Table S2). We find very good agreement among colony-specific D-values within each taxon (2-7\% RSD; Table S2). This agreement among D-values and $\mathrm{Ba} / \mathrm{Ca}_{\text {coral }}$ records constructed from contemporaneous co-located colonies demonstrates a high level of intercolony reproducibility and supports the validity of the $\mathrm{Ba} / \mathrm{Ca}$ coral proxy for Porites lobata, Pavona clavus and Pavona gigantea corals.

We find $\mathrm{D}_{B a}$ values ranging from $\sim 1.0$ to $\sim 1.4$ for the three coral genera included in this study (Table S2). These values are similar to those of other aragonitic surface and deep sea corals ( 1.3-1.5), high-Mg calcite deep sea corals $(\sim 1.3)$, and inorganic aragonite precipitation experiments $(\sim 1.5)$, but differ from foraminiferal calcite $(0.15)$, supporting the hypothesis that surface corals incorporate $\mathrm{Ba}$ via ionic substitution of $\mathrm{Ba}$ for $\mathrm{Ca}$ to form witherite $\left(\mathrm{BaCO}_{3}\right.$; Kitano et al., 1971; Lea et al., 1989; Dietzel et al., 2004; Anagnostou et al., 2011; Hönisch et al., 2011; LaVigne et al., 2011). Therefore, we also compared the composite taxa-specific regressions expressed as $\mathrm{Ba} / \mathrm{Ca}_{\text {coral }}$ vs. $\mathrm{Ba} / \mathrm{Ca}_{s w}$ (Fig. 6). In order to calculate $\mathrm{Ba} / \mathrm{Ca}_{s w}$ for these regressions, we coupled our $\mathrm{Ba}_{S W}$ measurements with estimates of $\mathrm{Ca}_{s w}$ scaled to salinity through the study period (based on average surface $\mathrm{Ca}_{s w}$ of 10.2 $\mathrm{mmol} / \mathrm{kg}$ and salinity of 35.09 for Pacific surface waters; de Villiers, 1998). The $\mathrm{Ba} / \mathrm{Ca}_{s w}$ record was smoothed and resampled in the same manner as the $\mathrm{Ba}_{S W}$ record in order to assign $\mathrm{Ba} / \mathrm{Ca}_{s w}$ values to the $\mathrm{Ba} / \mathrm{Ca}$ data points from each colony (Section 2.3).

Based on the evidence for an ionic substitution barium incorporation mechanism, we would expect that a coral grown in seawater containing no barium would have no skeletally incorporated $\mathrm{Ba}$. Thus, we compared the unforced Deming regressions of $\mathrm{Ba} / \mathrm{Ca}$ vs. $\mathrm{Ba}_{S W}$ and $\mathrm{Ba} / \mathrm{Ca}_{S W}$ against ordinary least squares (OLS) regressions forced through the origin. We find that the OLS regressions of $\mathrm{Ba} / \mathrm{Ca}_{\text {coral }} \mathrm{vs}$. $\mathrm{Ba}_{S W}$ forced through the origin fall within the standard errors of the unforced individual colony linear regressions for all but two colonies (PC1 and PG3). In addition, across the range of $\mathrm{Ba}_{S W}$ values studied here, for Porites lobata and Pavona clavus, the forced and unforced taxa-specific linear regressions of $\mathrm{Ba} / \mathrm{Ca} \mathrm{a}_{\text {coral }}$ vs. $\mathrm{Ba}_{S W}$ and $\mathrm{Ba} / \mathrm{Ca}_{S W}$ agree within the uncertainty (Fig. 5, Fig. 6). This agreement suggests that applying D- values (or $\mathrm{Ba} / \mathrm{Ca}_{\text {coral }}-\mathrm{Ba} / \mathrm{Ca}_{S W}$ regressions forced through the origin: Eqns. 5-6) 
495

496

497

498

499

500

501

502

503

504

505

506

507

508

509

510

511

512

513

514

515

516

517

518

519

520

521

522

523

524

525

526

527

528

529

530

531

532

533

534

535

536

537

538

539

to Porites lobata and Pavona clavus corals corresponding to the range of $\mathrm{Ba} / \mathrm{Ca}$ values studied here would yield results that fall within the uncertainty of the $\mathrm{Ba}_{S W}$ regression calibrations reported in Section 3.2.2 (Eqns. 2-4; if estimates of $\mathrm{Ca}_{S W}$ variations with sea surface salinity were taken into account). In addition, the uncertainty in absolute $\mathrm{Ba}_{S W}$ values reconstructed using Equations 5 and 6 would be much lower than that resulting from the unforced colony regressions reported above $\left( \pm \sim 2-4 \mathrm{nmol} / \mathrm{kg} \mathrm{Ba}{ }_{S W}\right.$ for the range of $\mathrm{Ba}_{S W}$ values studied here: $\sim 40-70 \mathrm{nmol} / \mathrm{kg}$ or $\sim 5-6 \%$ ). For Pavona gigantea corals, however, the forced regressions do not fall within the uncertainty of the unforced regressions (Fig. 5c, Fig. 6c). The low number of data points in the upper range of the Pavona gigantea regressions suggests that additional data spanning a broader range of $\mathrm{Ba}_{S W}$ values will likely be required before robust calibrations can be applied to Pavona gigantea coral records.

$$
\begin{aligned}
& \mathrm{Ba} / \mathrm{Ca}_{\text {Porites lobata }}=1.18 \pm 0.03 *\left(\mathrm{Ba} / \mathrm{Ca}_{S W}\right) ; \mathrm{p}<0.0001 ; \mathrm{n}=20 \\
& \mathrm{Ba} / \mathrm{Ca}_{\text {Pavona clavus }}=1.00 \pm 0.03 *\left(\mathrm{Ba} / \mathrm{Ca}_{S W}\right) ; \mathrm{p}<0.0001 ; \mathrm{n}=18
\end{aligned}
$$

Interestingly, the $\mathrm{Ba} / \mathrm{Ca}$ regression slopes and y-intercepts calculated for the Panama surface corals are comparable to those calculated for aragonitic and calcitic deep-sea corals (Fig. S3; Eq. 5-6; Anagnostou et al., 2011; LaVigne et al., 2011). This agreement between surface and deep-sea corals and corals of different calcium carbonate polymorphs further supports an inorganic Ba incorporation mechanism that is not a function of so-called "vital effects" driven by factors such as the presence of symbionts.

In summary, our data support an inorganic substitution incorporation mechanism for barium in surface-dwelling corals, based on the following evidence: (1) A high degree of intercolony reproducibility in $\mathrm{Ba} / \mathrm{Ca}_{\text {coral }}$ records (Table 1, Fig. 3) and D-values (Table S2), (2) overlap between unforced regression standard errors with those forced through the origin for Porites lobata and Pavona clavus corals spanning the range of values studied here (Figs. 5-6), and (3) general agreement between surface coral barium D-values (or $\mathrm{Ba} / \mathrm{Ca} a_{\text {coral }}$ vs. $\mathrm{Ba} / \mathrm{Ca}_{s w}$ regressions forced through the origin) and those of non-symbiont bearing deep-sea corals (Fig. S3).

\subsubsection{Application of the $B a / C a$ Proxy}

The first study to reconstruct upwelling trends from a Galápagos Pavona clavus $\mathrm{Ba} / \mathrm{Ca}_{\text {coral }}$ record lacked the species-specific calibration needed to quantify Ba $\mathrm{B}_{S W}$ (Lea et al., 1989). With the calibrations provided by this study, we can now evaluate the effect of using estimated D-values based on other coral species vs. species-specific calibrations. Lea et al., (1989) applied the best estimate of $\mathrm{D}_{B a}$ available at the time ( 1.3 based on Bermuda $M$. annularis and $D$. labyrinthiformis corals) to their $P$. clavus $\mathrm{Ba} / \mathrm{Ca}_{\text {coral }}$ record to estimate the degree of $\mathrm{Ba}_{S W}$ variability through several upwelling periods. This revealed $\mathrm{Ba}_{S W}$ values ranging from $\sim 33 \mathrm{nmol} / \mathrm{kg}$ during warm stratified El Niño conditions to $\sim 38 \mathrm{nmol} / \mathrm{kg}$ during the coolest SST upwelling intervals (Fig. 7). The $\mathrm{D}_{B a}$ values calculated from our Panamá Pavona clavus corals (0.95-1.08) are lower than those used by Lea et al. (1989), suggesting 
that the $\mathrm{Ba}_{S W}$ concentrations reported by Lea et al. may have been underestimated. Applying the Pavona clavus multi-colony calibration equation based on our Panamá corals to the Pavona clavus record (Lea et al. 1989; Fig. 7) suggests that $\mathrm{Ba}_{S W}$ concentrations in Galápagos surface waters were $\sim 7-10 \mathrm{nmol} / \mathrm{kg}$ higher than originally estimated. We find values closer to $\sim 40 \mathrm{nmol} / \mathrm{kg}$ during warm stratified periods and $45-49 \mathrm{nmol} / \mathrm{kg}$ during cool upwelling periods. These values are in reasonable agreement with $\mathrm{Ba}_{S W}$ measurements made more recently in a non-upwelling region of NE tropical Pacific $\sim 35-42 \mathrm{nmol} / \mathrm{kg}$ (Esser and Volpe, 2002). The absolute change in $\mathrm{Ba}_{S W}$ between warm and cool periods based on our calibration is roughly comparable to that estimated by Lea et al. $(1989 ; \sim 9-10 \mathrm{nmol} / \mathrm{kg}$ vs. $\sim 7$ $\mathrm{nmol} / \mathrm{kg}$, respectively; Fig. 7). This re-analysis of the Galápagos record demonstrates differences in $\mathrm{Ba}$ incorporation between taxa and underscores the importance of using species-specific calibrations or $\mathrm{D}_{B a}$ values to reconstruct $\mathrm{Ba}_{S W}$ accurately (e.g. Pingatore et al., 1989; Pretet et al., 2014).

\subsection{Other Potential Influences on Coral Ba/Ca}

\subsubsection{Temperature}

Sea surface temperature, a known driver of thermodynamically regulated incorporation of cations in marine carbonates, varies with upwelling intensity in the Gulf of Panamá. Although we cannot tease out the influence of SST on $\mathrm{Ba} / \mathrm{Ca}$ in these corals because of covariation in SST and $\mathrm{Ba}_{S W}$ at this site, it is unlikely that SST drives the incorporation of $\mathrm{Ba}$ observed in our data. Previous studies have suggested that barium incorporation in coral aragonite is inversely affected by temperature (Hart and Cohen, 1996; Dietzel et al., 2004; Gaetani and Cohen, 2006). Our data, however, reveal the opposite trend if any: with cool SST upwelling periods corresponding to lower $\mathrm{Ba} / \mathrm{Ca}_{\text {coral }}$ values and vice versa during warm summer conditions (Fig. 1, Fig. 3). Therefore, it is unlikely that SST is the primary driver of the seasonal $\mathrm{Ba} / \mathrm{Ca}_{\text {coral }}$ variation apparent in our data. Even still, an inverse temperature effect on $\mathrm{Ba} / \mathrm{Ca}_{\text {coral }}$ would only slightly dampen the increase in $\mathrm{Ba} / \mathrm{Ca}$ coral observed during the study period (by $\sim-0.4-1 \mu \mathrm{mol} / \mathrm{mol}$ or a decrease in $\mathrm{D}$ of $\sim 0.3$ : based on relationships reported by Dietzel et al. (2004) and Gaetani and Cohen (2006).

\subsubsection{Salinity}

Although our data reveal an inverse relationship between SSS and $\mathrm{Ba} / \mathrm{Ca}_{\text {coral }}$, this trend is more likely to result from barium delivery to the coastal surface waters by freshwater runoff than a salinity effect on barium incorporation. A recent study has shown that $\mathrm{Ba} / \mathrm{Ca}_{\text {coral }}$ in other surface coral species ( $M$. verrucosa, Acropora sp., and S. pistillata) is resistant to imposed changes in salinity ranging from 36-40 under experimental culturing conditions (Pretet et al., 2014).

\section{CONCLUSIONS}

The data presented here support the continued interpretation of skeletal $\mathrm{Ba} / \mathrm{Ca}$ in shallow water hermatypic corals as a tracer of surface water barium concentration. Collectively, our high-resolution seawater and skeletal coral trace element records demonstrate the complexities associated with using indirect nutrient proxies to reconstruct upwelling in coastal areas (Matthews et al., 2008; LaVigne et al., 2010; Grottoli et al., 2013). These studies reveal the value of combining multiple surface coral proxies to provide a detailed 
understanding of biogeochemical dynamics of upwelling regimes in the past. Using data from triplicate coral colonies we present the first taxa-specific $\mathrm{Ba} / \mathrm{Ca}_{\text {coral }}$ calibrations based on multiple co-located colonies and a contemporaneous in situ $\mathrm{Ba}_{S W}$ seawater record. These equations can now be applied to downcore records from Porites lobata and Pavona clavus corals to quantify high-resolution changes in absolute $\mathrm{Ba}_{S W}$ concentration, a substantial improvement over interpreting relative changes in $\mathrm{Ba} / \mathrm{Ca}_{\text {coral }}$ alone. These results suggest that larger corals from regions where precipitation is influenced by ITCZ position could be used to reconstruct ITCZ and ENSO variability using runoff records derived from $\mathrm{Ba} / \mathrm{Ca}$ coral. The calibrations presented here could also be used to quantify paleo- $\mathrm{Ba}_{S W}$ concentration from fossilized surface corals to reconstruct millennial-scale changes in paleo $\mathrm{Ba}_{S W}$ inventory and water mass distribution resulting from variations in circulation, riverine input, upwelling, or removal from surface waters via barite formation (e.g. Lea and Boyle, 1990; Lea and Boyle, 1991). Additional work constructing longer-term calibrations and evaluating inter-colony reproducibility will likely lead to even more robust calibrations with reduced uncertainty, allowing for the broad application of the $\mathrm{Ba} / \mathrm{Ca}_{\text {coral }}$ proxy.

Acknowledgements. We thank Kathryn Matthews for carrying out fieldwork for this project, P. Field, C. Theodore and Y. Matsui for sample preparation and analyses, and L. D'Croz of the Smithsonian Tropical Research Institute for Gulf of Panamá oceanographic data and field logistics. K. Matthews and J. Palardy were students in A. Grottoli's laboratory when the fieldwork was conducted. Principal funding support was provided by the American Chemical Society Petroleum Research Fund (ACS PRF Grant 47625-AC2 to R. Sherrell and 41740-G2 to A. Grottoli). Additional funding was provided by the National Science Foundation (OCE 0752544 to R. Sherrell and 0610487 to A. Grottoli) and the Andrew Mellon Foundation (to A. Grottoli). We appreciate the constructive comments from three anonymous reviewers; the quality of this manuscript was improved as a result.

\section{FIGURE CAPTIONS}

\section{FIGURE 1:}

In situ sea surface temperature (SST), sea surface salinity (SSS), dissolved barium $\left(\mathrm{Ba}_{S w}\right)$, cadmium $\left(\mathrm{Cd}_{S W}\right.$; Grottoli et al., 2013), and soluble reactive phosphate $\left(\mathrm{PO}_{4}\right.$; $\mathrm{LaVigne}$ et al., 2010) measured through the 2003 study period in the Gulf of Panamá. Uncertainties on $\mathrm{Ba}_{S W}, \mathrm{Cd}_{S W}$, and $\mathrm{PO}_{4}$ measurements are $1.173 \mathrm{nmol} / \mathrm{kg} \mathrm{Ba}$ (average deviation about the mean for $\mathrm{n}=10$ pairs of replicate dilutions), $6.3 \mathrm{nmol} / \mathrm{kg} \mathrm{Cd}(\mathrm{RSD} ; \mathrm{n}=10)$, and $0.026 \mu \mathrm{mol} / \mathrm{kg}$ $\mathrm{PO}_{4}$ (average deviation about the mean for $\mathrm{n}=14$ pairs of analytical duplicates). Typical seasons of runoff minimum (February-March) and maximum (May-June) identified by light and dark grey shading, respectively (Forsbergh, 1969; D'Croz, 1991). Tick marks on time axis are first day of month. 
629 Dissolved barium ( $\mathrm{Ba}_{S W}$; this study) vs. sea surface salinity (SSS; Matthews et al., 2008) for the coral growth site in the Gulf of Panamá, measured through the study period.

\section{FIGURE 3:}

In situ $\mathrm{Ba}_{S W}$ time series (dotted line; left y-axis) and contemporaneous timescale-adjusted coral $\mathrm{Ba} / \mathrm{Ca}$ results (right y-axis) for triplicate colonies of Porites lobata (a) Pavona gigantea (b) and Pavona clavus (c) through the 2003 study period in the Gulf of Panamá. Uncertainty on coral $\mathrm{Ba} / \mathrm{Ca}$ data points, based on repeat measurements of coral consistency standard, is $0.58 \mu \mathrm{mol} / \mathrm{mol}(1 \mathrm{SD} ; \mathrm{n}=24)$. Uncertainty in $\mathrm{Ba}_{S W}$ is $1.173 \mathrm{nmol} / \mathrm{kg}$ based on the average deviation about the mean for duplicate dilutions of 10 samples. Tick marks on time axis are first day of month.

\section{FIGURE 4:}

Local $\mathrm{Ba} / \mathrm{Ca}-\mathrm{Ba}_{\mathrm{SW}}$ calibrations for individual colonies of Gulf of Panamá Porites lobata (ac) Pavona gigantea (d-f) and Pavona clavus (g-i) colonies. Regressions were calculated from coral $\mathrm{Ba} / \mathrm{Ca}$ (y-axis) and local re-sampled $\mathrm{Ba}{ }_{s W}$ time-series (x-axis; see text). $\mathrm{X}$ and $\mathrm{Y}$ error bars represent average deviation about the mean for duplicate $\mathrm{Ba}_{S W}$ measurements $(\mathrm{n}=10$ pairs of replicate dilutions; avg. dev. $=1.173 \mathrm{nmol} / \mathrm{kg} \mathrm{Ba}$ ), and repeat measurements of coral consistency standard $(\mathrm{SD}=0.58 \mu \mathrm{mol} / \mathrm{mol} ; \mathrm{n}=24)$ respectively. Deming model II equations (solid black lines) and linear regressions forced through the origin (dashed lines) are plotted for each colony.

\section{FIGURE 5:}

Multi-colony composite $\mathrm{Ba} / \mathrm{Ca}_{\text {coral }}$ - seawater barium concentration $\left(\mathrm{Ba}{ }_{s W}\right)$ calibrations for Gulf of Panamá Porites lobata (a) Pavona gigantea (b), and Pavona clavus (c) colonies. Regressions were calculated from coral $\mathrm{Ba} / \mathrm{Ca}$ pooled from three replicate colonies (y-axis) and local re-sampled $\mathrm{Ba}_{S W}$ time-series (x-axis; see text). $\mathrm{X}$ and $\mathrm{Y}$ error bars represent mean deviation for duplicate $\mathrm{Ba}_{S W}$ measurements ( $\mathrm{n}=10$ pairs of replicate dilutions; (avg. dev. = $1.173 \mathrm{nmol} / \mathrm{kg} \mathrm{Ba}$ ), and repeat measurements of coral consistency standard ( $\mathrm{SD}=0.58$ $\mu \mathrm{mol} / \mathrm{mol} ; \mathrm{n}=24$ ) respectively. Deming model II regression equations (solid black lines) and linear regressions forced through the origin (dashed lines) are plotted for each taxon.

\section{FIGURE 6:}

Multi-colony composite $\mathrm{Ba} / \mathrm{Ca}_{\text {coral }}$ - seawater barium/calcium ratio $\left(\mathrm{Ba} / \mathrm{Ca}_{S W}\right)$ calibrations for Gulf of Panamá Porites lobata (a) Pavona gigantea (b), and Pavona clavus colonies. Regressions were calculated from coral $\mathrm{Ba} / \mathrm{Ca}$ pooled from three replicate colonies (y-axis) and local re-sampled $\mathrm{Ba} / \mathrm{Ca}_{S W}$ time-series (x-axis; see text). X error bars represent mean deviation for duplicate $\mathrm{Ba}{ }_{S W}$ measurements $(\mathrm{n}=10$ pairs of replicate dilutions avg. dev. $=$ $1.173 \mathrm{nmol} / \mathrm{kg} \mathrm{Ba}$ ) propagated to estimated uncertainty on mean $\mathrm{Ba} / \mathrm{Ca}{ }_{S W}$ calculated for the study period $(5.324 \mu \mathrm{mol} / \mathrm{kg})$. Y error bars represent $\mathrm{Ba} / \mathrm{Ca}$ coral uncertainty based on repeat measurements of coral consistency standard $(\mathrm{SD}=0.58 \mu \mathrm{mol} / \mathrm{mol} \mathrm{Ba} / \mathrm{Ca} ; \mathrm{n}=24)$. Deming model II regression equations (solid black lines) and linear regressions forced through the origin (dashed lines) are plotted for each taxon. 


\section{FIGURE 7:}

$674 \mathrm{Ba}_{S W}$ values reconstructed from the Galápagos Pavona clavus $\mathrm{Ba} / \mathrm{Ca}$ record published by Lea 675 et al., (1989; data downloaded from

676 http://hurricane.ncdc.noaa.gov/pls/paleox/f?p=519:1::::P1_STUDY_ID:1849). Dashed line 677 (black circles) represents $\mathrm{Ba}_{S W}$ calculated from D-value estimated by Lea et al., 1989 based 678 on Bermuda M. annularis and D. labrynthiformis corals $(\mathrm{D}=1.3)$. Solid lines represent $\mathrm{Ba}_{S W}$ 679 reconstructed from Gulf of Panama $P$. clavus data (this study) using $P$. clavus composite 680 regression of $\mathrm{Ba} / \mathrm{Ca}$ against $\mathrm{Ba}_{S W}$ (Eqn. 4; grey diamonds) or $\mathrm{D}=1.0$ (Eqn. 6; black squares). 681 Reconstructions using D-values incorporate estimates of $\mathrm{Ca}_{s w}$ scaled with salinity from this 682 region $\left(\mathrm{Ca}_{s w}\right.$ of $10.2 \mathrm{mmol} / \mathrm{kg}$ and salinity of 34.3 for Pacific surface waters de Villiers, 683 1998; Sweet et al., 2007). 
Alibert, c., Kinsley, L., Fallon, S., McCulloch, M., Berkelmans, R., McAllister, F., 2003. Source of trace element variability in Great Barrier Reef corals affected by the Burdekin flood plumes. Geochimica et Cosmochimica Acta 67, 231-246.

Allison, N., Finch, A.A., 2007. High temporal resolution $\mathrm{Mg} / \mathrm{Ca}$ and $\mathrm{Ba} / \mathrm{Ca}$ records in

Anagnostou, E., Sherrell, R.M., Gagnon, A., LaVigne, M., Field, M.P., McDonough, W.F., 2011. Seawater nutrient and carbonate ion concentrations recorded as $\mathrm{P} / \mathrm{Ca}, \mathrm{Ba} / \mathrm{Ca}$, and $\mathrm{U} / \mathrm{Ca}$ in the deep-sea coral Desmophyllum dianthus. Geochimica et Cosmochimica Acta 75, 25292543. coral skeletons. Journal of Experimental Marine Biology and Ecology 167, 91-108. massive coral skeletons. Part II: distortions in skeletal records of annual climate cycles due to growth processes. Journal of Experimental Marine Biology and Ecology 194, 251-275. C., 1992. Sea-surface temperature from coral skeletal strontium/calcium ratios. Science 257, 644-647.

Bishop, J.K.B., 1988. The barite-opal-organic carbon association in oceanic particulate matter. Nature 332, 341-343.

734 Carilli, J.E., McGregor, H.V., Gaudry, J.J., Donner, S.D., Gagan, M.K., Stevenson, S., 735 Wong, H., Fink, D., 2014. Equatorial Pacific coral geochemical records show recent 736 weakening of the Walker Circulation. Paleoceanography 29, 1031-1045.

737 Carriquiry, J.D., Horta-Puga, G., 2010. The Ba/Ca record of corals from the Southern Gulf of 738 Mexico: contributions from land-use changes, fluvial discharge and oil-drilling muds. Mar 739 Pollut Bull 60, 1625-1630. 
740 Coffey, M., Dehairs, F., Collette, O., Luther, G., Church, T., Jickells, T., 1997. The 741 Behaviour of Dissolved Barium in Estuaries. Estuarine, Coastal and Shelf Science 45, 113742121.

743 Cohen, A.L., Thorrold, S.R., 2007. Recovery of temperature records from slow-growing 744 corals by fine scale sampling of skeletons. Geophysical Research Letters 34, L17706.

745 D'Croz, L., Del Rosario, J.B., Gomez, J.A., 1991. Upwelling and phytoplankton in the Bay of 746 Panama. Rev. Biol. Trop. 39, 233-241.

747 de Villiers, S., 1998. Excess dissolved Ca in the deep ocean: a hydrothermal hypothesis. 748 Earth and Planetary Science Letters 164, 627-641.

749 de Villiers, S., Shen, G.T., Nelson, B.K., 1994. The $\mathrm{Sr} / \mathrm{Ca}$ - temperature relationship in 750 coralline aragonite: Influence of variability in $(\mathrm{Sr} / \mathrm{Ca})_{\text {sewater }}$ and skeletal growth parameters.

751 Geochimica et Cosmochimica Acta 58, 197-208.

752 Dehairs, F., Chesselet, R., Jedwab, J., 1980. Discrete suspended particles of barite and the 753 barium cycle in the open ocean. Earth and Planetary Science Letters 49, 528-550.

754 .DeLong, K.L., Falnnery, J.A., Poore, R.Z., Quinn, T.M., Maupin, C.R., Lin, K., Shen, C.-C., 755 2014. A reconstruction of sea surface temperature variability in the southeastern Gulf of 756 Mexico from 1734 to 2008 C.E. using cross-dated Sr/Ca records from the coral Siderastrea 757 siderea. Paleoceanography 29, doi:10.1002/ 2013PA002524.

758 DeLong, K.L., Flannery, J.A., Maupin, C.R., Poore, R.Z., Quinn, T.M., 2011. A coral Sr/Ca 759 calibration and replication study of two massive corals from the Gulf of Mexico.

760 Palaeogeography, Palaeoclimatology, Palaeoecology 307, 117-128.

761 DeLong, K.L., Quinn, T.M., Taylor, F.W., 2007. Reconstructing twentieth-century sea 762 surface temperature variability in the southwest Pacific: A replication study using multiple 763 coral $\mathrm{Sr} / \mathrm{Ca}$ records from New Caledonia. Paleoceanography 22, PA4212.

764 DeLong, K.L., Quinn, T.M., Taylor, F.W., Shen, C.-C., Lin, K., 2013. Improving coral-base 765 paleoclimate reconstructions by replicating 350years of coral $\mathrm{Sr} / \mathrm{Ca}$ variations.

766 Palaeogeography, Palaeoclimatology, Palaeoecology 373, 6-24. 
Dietzel, M., Gussone, N., Eisenhauer, A., 2004. Co-precipitation of Sr2+ and Ba2+ with 768 aragonite by membrane diffusion of $\mathrm{CO} 2$ between 10 and $50{ }^{\circ} \mathrm{C}$. Chemical Geology 203, 769 139-151.

770 Esser, B.K., Volpe, A.M., 2002. At-sea high-resolution chemical mapping: extreme barium 771 depletion in the North Pacific surface water. Marine Chemistry 79, 67-79.

772 Fallon, S.J., McCulloch, M.T., van Woesik, R., Sinclair, D.J., 1999. Corals at their latitudinal 773 limits: laser ablation trace element systematics in Porites from Shirigai Bay, Japan. Earth and 774 Planetary Science Letters 172, 221-238.

775 Field, M.P., LaVigne, M., Murphy, K.R., Ruiz, G.M., Sherrell, R.M., 2007. Direct 776 determination of $\mathrm{P}, \mathrm{V}, \mathrm{Mn}, \mathrm{As}, \mathrm{Mo}, \mathrm{Ba}$, and $\mathrm{U}$ in seawater by SF-ICP-MS. Journal of 777 Analytical Atomic Spectrometry 22, 1145-1151.

778 Fleitmann, D., Dunbar, R.B., McCulloch, M., Mudelsee, M., Vuille, M., McClanahan, T.R., 779 Cole, J.E., Eggins, S., 2007. East African soil erosion recorded in a 300 year old coral colony 780 from Kenya. Geophys. Res. Lett. 34, L04401.

781 Forsbergh, E.D., 1969. On the climatology, oceanography and fisheries of the Panama bight, 782 Inter-American tropical tuna commission, La Jolla, California.

783 Gaetani, G.A., Cohen, A.L., 2006. Element partitioning during precipitation of aragonite 784 from seawater: a framework for understanding paleoproxies. Geochim. Cosmochim. Acta 70, $785 \quad 4617-4634$.

786 Gagan, M.K., Chivas, A.R., Isdale, P., 1994. High-resolution isotopic records from corals 787 using ocean temperature and mass-spawning chronometers. Earth and Planetary Science 788 Letters 121, 549-558.

789 Gagan, M.K., Dunbar, G.B., Suzuki, A., 2012. The effect of skeletal mass accumulation 790 inPoriteson coral $\mathrm{Sr} / \mathrm{Ca}$ and $\delta^{18} \mathrm{O}$ paleothermometry. Paleoceanography 27, PA1203.

791 Ganeshram, R.S., R. François, Commeau, J., Brown-Leger, S.L., 2003. An experimental 792 investigation of barite formation in seawater. Geochimica et Cosmochimica Acta 67, 25997932605. 
794 Goodkin, N.F., Hughen, K.A., Cohen, A.L., 2007. A multicoral calibration method to 795 approximate a universal equation relating $\mathrm{Sr} / \mathrm{Ca}$ and growth rate to sea surface temperature.

796 Paleoceanography 22, PA1214.

797 Grottoli, A.G., Matthews, K.A., Palardy, J.E., McDonough, W.F., 2013. High resolution 798 coral Cd measurements using LA-ICP-MS and ID-ICP-MS: Calibration and interpretation.

799 Chemical Geology 356, 151-159.

800 Guilderson, T.P., Schrag, D.P., 1998. Abrupt shift in subsurface temperatures in the tropical 801 Pacific associated with changes in El Niño. Science 281, 240-243.

802 Hart, S.R., Cohen, A.L., 1996. An ion probe study of annual cycles of Sr/Ca and other trace 803 elements in corals. Geochim. Cosmochim. Acta 60, 3075-3084.

804 Hönisch, B., Allen, K.A., Russell, A.D., Eggins, S.M., Bijma, J., Spero, H.J., Lea, D.W., Yu, 805 J., 2011. Planktic foraminifers as recorders of seawater Ba/Ca. Marine Micropaleontology $80679,52-57$.

807 Horta-Puga, G., Carriquiry, J.D., 2012. Coral Ba/Ca molar ratios as a proxy of precipitation 808 in the northern Yucatan Peninsula, Mexico. Applied Geochemistry 27, 1579-1586.

809 Kitano, Y., Kanamori, K., Oomori, T., 1971. Measurements of distribution coefficients of 810 strontium and barium between carbonate precipitate and solution -Abnormally high values of 811 distribution coefficients measured at early stages of carbonate formation. Geochemical 812 Journal 4, 183-206.

813 LaVigne, M., Hill, T.M., Spero, H.J., Guilderson, T.P., 2011. Bamboo coral Ba/Ca:

814 Calibration of a new deep ocean refractory nutrient proxy. Earth and Planetary Science

815 Letters 312, 506-515.

816 LaVigne, M., Matthews, K.A., Grottoli, A.G., Cobb, K.M., Anagnostou, E., Cabioch, G., 817 Sherrell, R.M., 2010. Coral skeleton P/Ca proxy for seawater phosphate: Multi-colony 818 calibration with a contemporaneous seawater phosphate record. Geochimica et 819 Cosmochimica Acta 74, 1282-1293.

820 Lea, D.W., Boyle, E.A., 1989. Barium content of benthic foraminifera controlled by bottom821 water composition. Nature 338, 751-753. 
822 Lea, D.W., Boyle, E.A., 1990. Foraminiferal reconstruction of barium distributions in water 823 masses of the global oceans. Paleoceanography 5, 719-742.

824 Lea, D.W., Boyle, E.A., 1991. Barium in planktonic foraminifera. Geochimica et

825 Cosmochimica Acta 55, 3321-3331.

826 Lea, D.W., Shen, G.T., Boyle, E.A., 1989. Coralline barium records temporal variability in 827 equatorial Pacific upwelling. Nature 340, 373-375.

828 Lea, D.W., Spero, H.J., 1992. Experimental determination of barium uptake in individual 829 shells of the planktonic foraminifera Orbulina universa. Geochimica et Cosmochimica Acta $83056,2673-2680$.

831 Li, Y.H., Chan, L.H., 1979. Desorption of Ba and ${ }^{226}$ Ra from river-borne sediments in the 832 Hudson River Estuary. Earth and Planetary Science Letters 43, 343-350.

833 Linsley, B.K., Zhang, P., Kaplan, A., Howe, S.S., Wellington, G.M., 2008. Interdecadal834 decadal climate variability from multicoral oxygen isotope records in the South Pacific 835 Convergence Zone region since 1650 A.D. Paleoceanography 23, PA2219.

836 Maina, J., de Moel, H., Vermaat, J.E., Bruggemann, J.H., Guillaume, M.M., Grove, C.A., 837 Madin, J.S., Mertz-Kraus, R., Zinke, J., 2012. Linking coral river runoff proxies with climate 838 variability, hydrology and land-use in Madagascar catchments. Mar Pollut Bull 64, $2047-$ 8392059.

840 Mallela, J., Lewis, S.E., Croke, B., 2013. Coral Skeletons Provide Historical Evidence of 841 Phosphorus Runoff on the Great Barrier Reef. PLoS ONE 8, e75663.

842 Matthews, K., McDonough, W., Grottoli, A., 2006. Cadmium measurements in coral 843 skeleton using isotope dilution-inductively coupled plasma-mass spectrometry.

844 Geochemistry, Geophysics, Geosystems 7, Q11021.

845 Matthews, K.A., 2007. Cadmium in coral skeleton: natural variability and in situ calibration, 846 Earth and Environmental Science. University of Pennsylvania, Pennsylvania, p. 163.

847 Matthews, K.A., Grottoli, A.G., McDonough, W.F., Palardy, J.E., 2008. Upwelling, species, 848 and depth effects on coral skeletal cadmium-to-calcium ratios $(\mathrm{Cd} / \mathrm{Ca})$. Geochimica et 849 Cosmochimica Acta 72, 4537-4550. 

record of increased sediment flux to the inner Great Barrier Reef since European settlement.

852 Nature 421, 727-730.

853 Montaggioni, L.F., Le Cornec, F., Corrège, T., Cabioch, G., 2006. Coral barium/calcium 854 record of mid-Holocene upwelling activity in New Caledonia, South-West Pacific.

855 Palaeogeography, Palaeoclimatology, Palaeoecology 237, 436-455.

856 Morse, J.W., Bender, M.L., 1990. Partition coefficients in calcite: examination of factors 857 influencing the validity of experimental results and their application to natural systems.

858 Chem. Geol. 82, 265-277.

859 Moyer, R.P., Grottoli, A.G., Olesik, J.W., 2012. A multiproxy record of terrestrial inputs to 860 the coastal ocean using minor and trace elements $(\mathrm{Ba} / \mathrm{Ca}, \mathrm{Mn} / \mathrm{Ca}, \mathrm{Y} / \mathrm{Ca})$ and carbon isotopes $861\left(\delta^{13} \mathrm{C}, \Delta{ }^{14} \mathrm{C}\right)$ in a nearshore coral from Puerto Rico. Paleoceanography 27, PA3205.

862 Nurhati, I.S., Cobb, K.M., Di Lorenzo, E., 2011. Decadal-Scale SST and Salinity Variations 863 in the Central Tropical Pacific: Signatures of Natural and Anthropogenic Climate Change.

864 Journal of Climate 24, 3294-3308.

865 Paillard, D., Labeyrie, L., Yiou, P., 1996. Macintosh program performs time-series analysis. 866 EOS Transactions 77, 379.

867 Pfeiffer, M., Dullo, W.-C., Zinke, J., Garbe-Schönberg, D., 2009. Three monthly coral Sr/Ca 868 records from the Chagos Archipelago covering the period of 1950-1995 A.D.:

869 reproducibility and implications for quantitative reconstructions of sea surface temperature 870 variations. International Journal of Earth Sciences 98, 53-66.

871 Pingatore, N.E., Rangel, Y., Kwarteng, A., 1989. Barium variation in Acropora palmata and 872 Montastrea annularis. Coral Reefs 8, 31-36.

873 Pretet, C., Reynaud, S., Ferrier-Pagès, C., Gattuso, J.-P., Kamber, B.S., Samankassou, E., 874 2014. Effect of salinity on the skeletal chemistry of cultured scleractinian zooxanthellate 875 corals: $\mathrm{Cd} / \mathrm{Ca}$ ratio as a potential proxy for salinity reconstruction. Coral Reefs 33, 169-180.

876 Prouty, N.G., Field, M.E., Stock, J.D., Jupiter, S.D., McCulloch, M., 2010. Coral Ba/Ca 877 records of sediment input to the fringing reef of the southshore of Moloka'i, Hawai'i over the 878 last several decades. Mar Pollut Bull 60, 1822-1835. 
879 Prouty, N.G., Hughen, K.A., Carilli, J., 2008. Geochemical signature of land-based activities 880 in Caribbean coral surface samples. Coral Reefs 27, 727-742.

881 R Core Team, 2012. R: A language and environment for statistical computing. R Foundation 882 for Statistical Computing, Vienna, Austria.

883 Robinson, C.D., Devalla, S., Monpais, M., Davies, I.M., 2009. Solution-based determination 884 of trace elements in biogenic carbonates: comparison of two sample introduction systems for 885 use in flow injection ICPMS analysis. Journal of Analytical Atomic Spectrometry 24, 939886943.

887 Rosenthal, Y., Field, M.P., Sherrell, R.M., 1999. Precise determination of element/calcium 888 ratios in calcareous samples using Sector Field Inductively Couple Plasma Mass

889 Spectrometry. Analytical Chemistry 71, 3248-3253.

890 Schrag, D.P., 1999. Rapid analysis of high-precision Sr/Ca ratios in corals and other marine 891 carbonates. Paleoceanography 14, 97-102.

892 Shen, G.T., Boyle, E.A., 1988. Determination of lead, cadmium and other trace metals in 893 annually-banded corals. Chem. Geol. 67, 47-62.

894 Shen, G.T., Boyle, E.A., Lea, D.W., 1987. Cadmium in corals as a tracer of historical 895 upwelling and industrial fallout. Nature 328, 794-896.

896 Sinclair, D.J., 2005. Non-river flood barium signals in the skeletons of corals from coastal 897 Queensland, Australia. Earth Plan. Sci. Lett. 237, 354-369.

898 Sinclair, D.J., McCulloch, M., 2004a. Corals record low mobile barium concentrations in teh 899 Burdekin River during the 1974 flood: evidence for limited Ba supply to rivers?

900 Palaeogeography, Palaeoclimatology, Palaeoecology 214, 155-174.

901 Sinclair, D.J., McCulloch, M.T., 2004b. Corals record low mobile barium concentrations in 902 the Burdekin River during the 1974 flood: evidence for limited Ba supply to rivers?

903 Palaeogeography, Palaeoclimatology, Palaeoecology 214, 155-174.

904 Swart, P.K., Elderfield, H., Greaves, M.J., 2002. A high-resolution calibration of Sr/Ca 905 thermometry using the Caribbean coral Montastraea annularis. Geochemistry Geophysics 906 Geosystems 3, 2002 GC000306. 
907 Sweet, W.V., Morrison, J.M., Kamykowski, D., Schaeffer, B.A., Banks, S., McCulloch, A., 908 2007. Water mass seasonal variability in the Galápagos Archipelago. Deep Sea Research Part 909 I: Oceanographic Research Papers 54, 2023-2035.

910 Taylor, R.B., Barnes, D.J., Lough, J.M., 1993. Simple models of density band formation in 911 massive corals. Journal of Experimental Marine Biology and Ecology 167, 109-125.

912 Wellington, G.M., Dunbar, R., Merlen, G., 1996. Calibration of stable oxygen isotope

913 signatures in Galápagos corals. Paleoceanography 11, 467-480.

914 Williams, B., Halfar, J., DeLong, K.L., Hetzinger, S., Steneck, R.S., Jacob, D.E., 2014.

915 Multi-specimen and multi-site calibration of Aleutian coralline algal $\mathrm{Mg} / \mathrm{Ca}$ to sea surface

916 temperature. Geochimica et Cosmochimica Acta 139, 190-204.

917 Winter, B., 2013. Linear models and linear mixed effects models in R with linguistic

918 applications. arXiv:1308.5499. University of California, Merced, Cognitive and Information

919 Sciences.

920

921

922 
Table 1: Correlation ( $r$ ) between $\mathrm{Ba} / \mathrm{Ca}$ records for replicate colonies of each taxa

\begin{tabular}{|c|c|c|}
\hline Porites lobata & PL2 & PL3 \\
\hline$\overline{P L 1}$ & $0.96(p=0.01 ; n=5)$ & $0.97(p=0.005 ; n=5)$ \\
\hline PL2 & - & $0.99(p=0.002 ; n=5)$ \\
\hline PL3 & - & - \\
\hline Pavona gigantea & PG2 & PG3 \\
\hline PG1 & $0.90(p=0.1 ; n=4)$ & $0.95(p=0.2 ; n=3)$ \\
\hline PG2 & - & $0.99(p=0.09 ; n=3)$ \\
\hline PG3 & - & - \\
\hline Pavona clavus & PC2 & PC3 \\
\hline PC1 & $0.86(p=0.06 ; n=5)$ & $0.92(p=0.01 ; n=6)$ \\
\hline PC2 & - & $0.95(p=0.01 ; n=5)$ \\
\hline PC3 & - & - \\
\hline
\end{tabular}




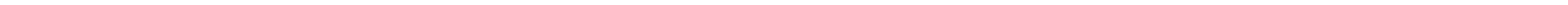




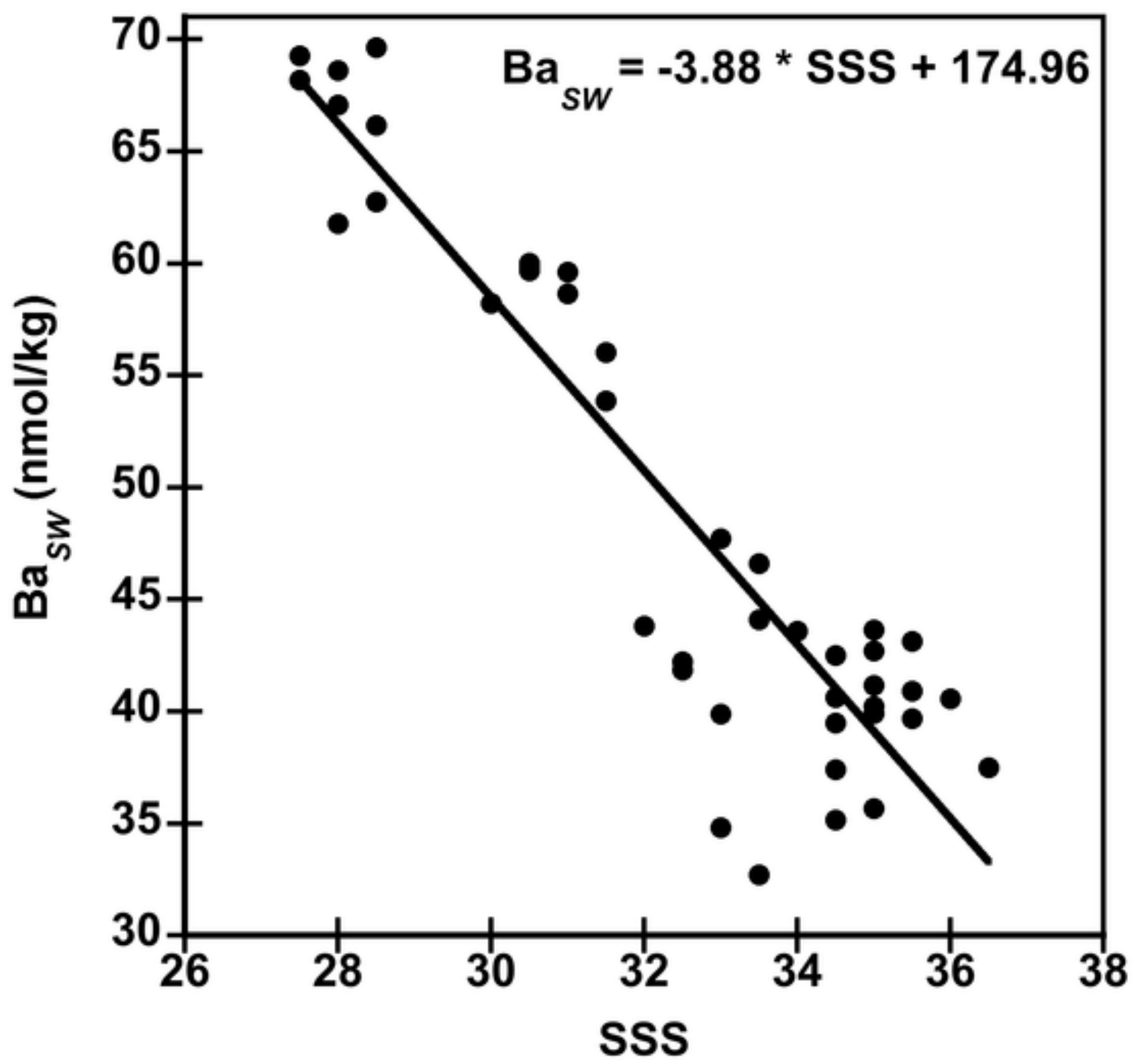



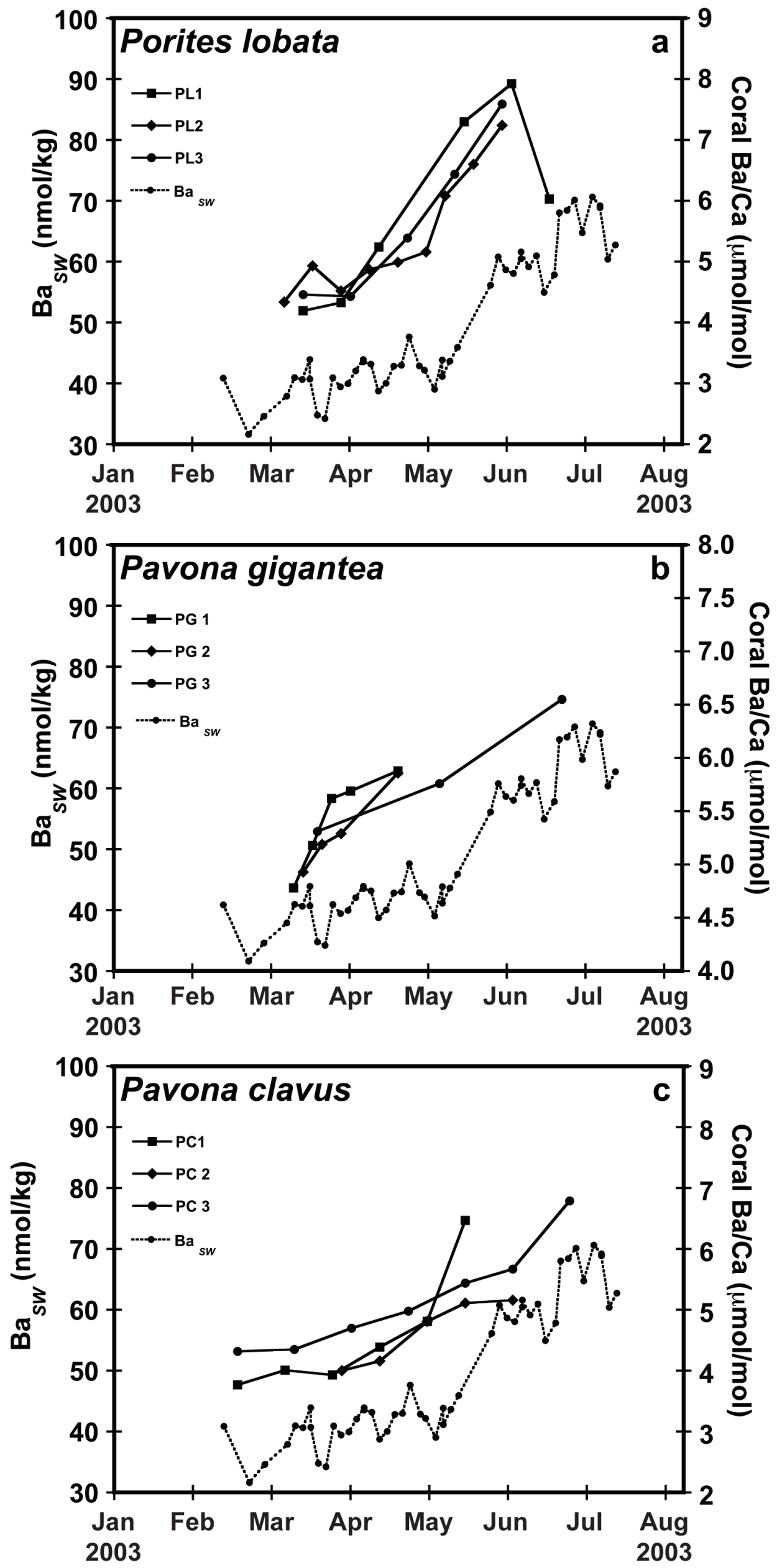
PL1
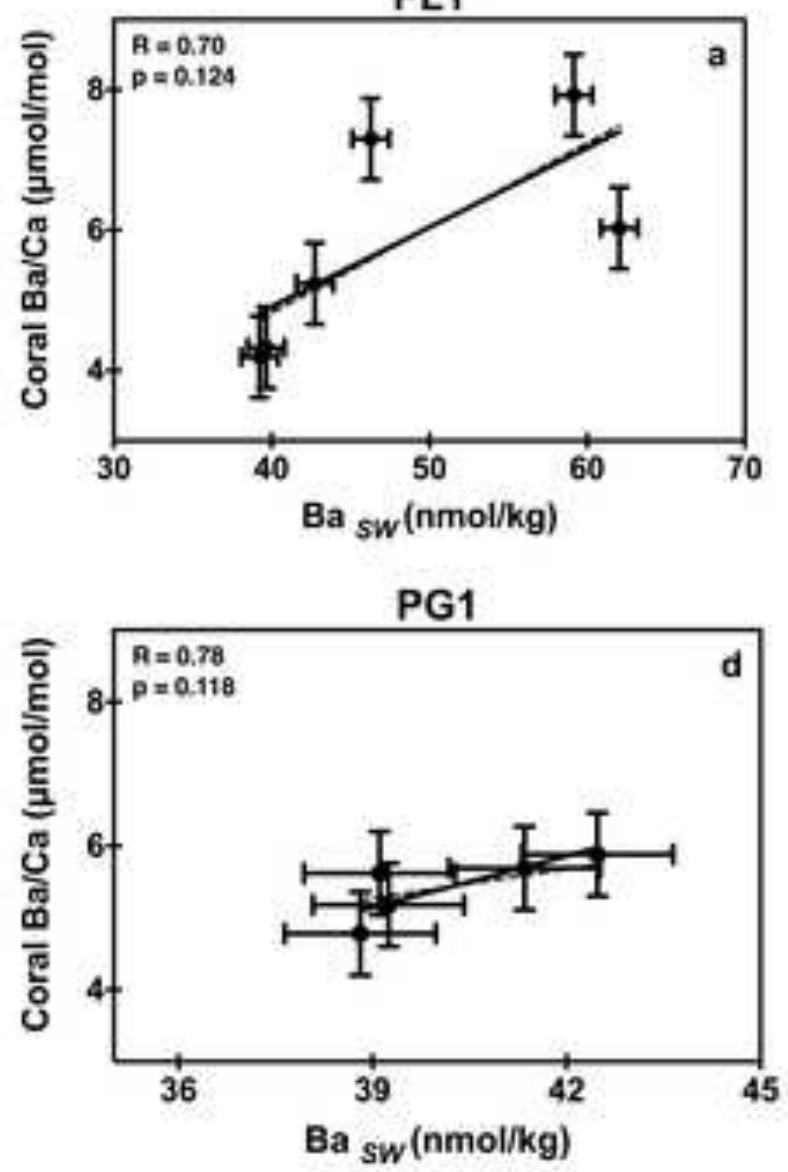

PC1

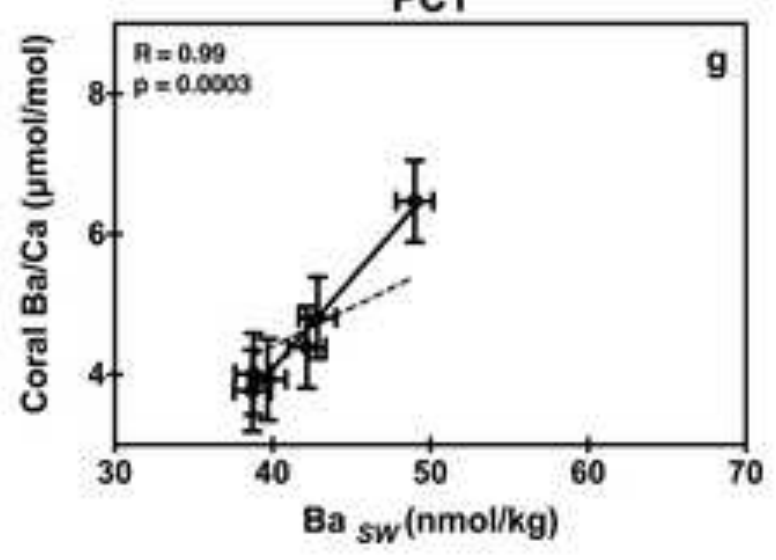

PL2

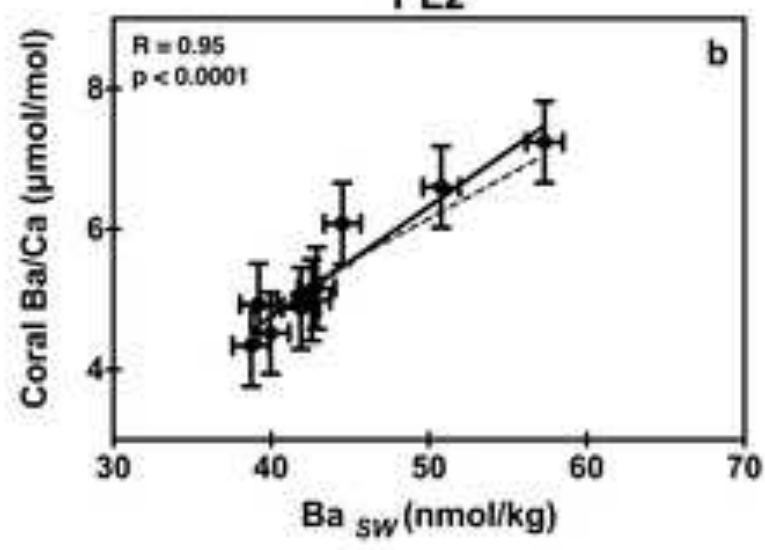

PG2

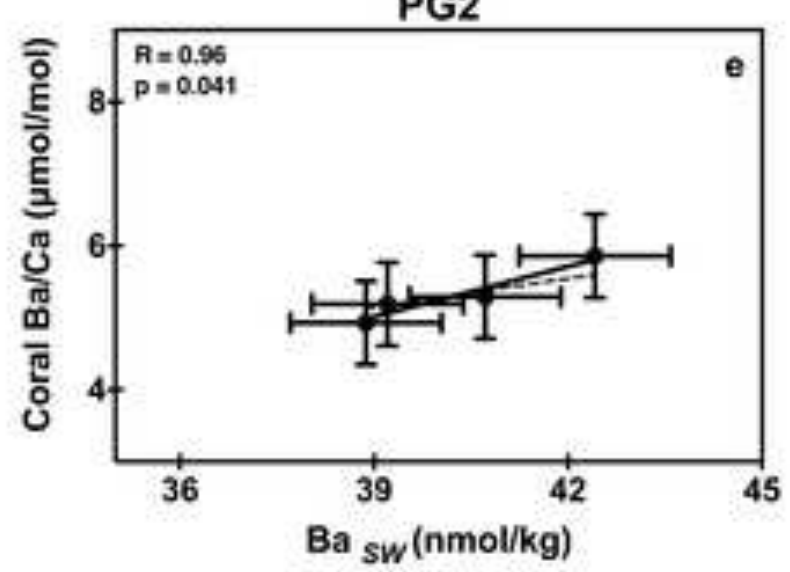

PC2

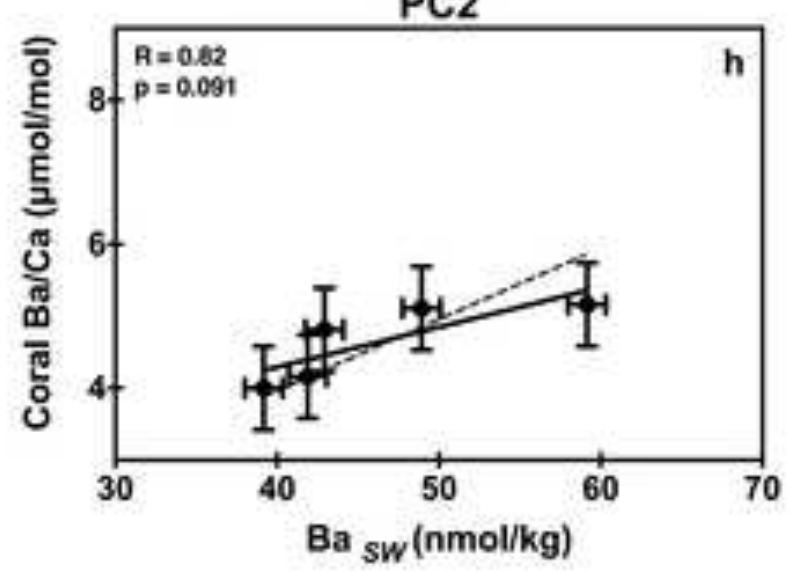

PL3

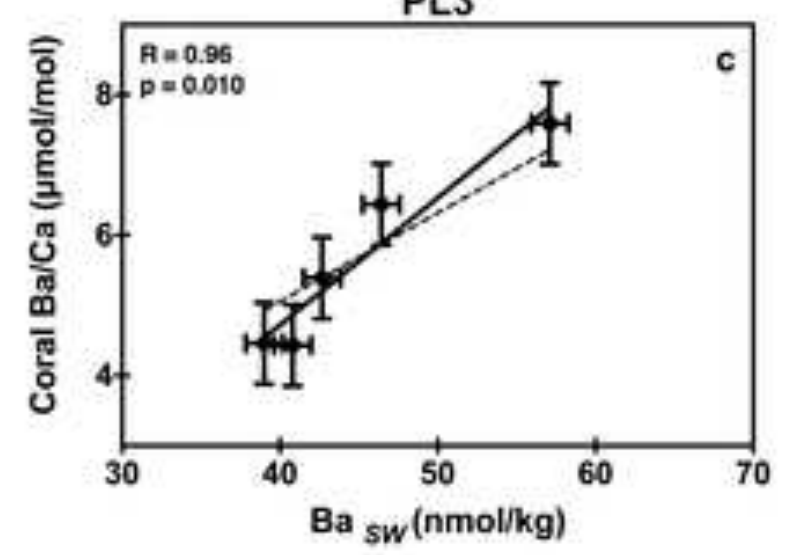

PG3

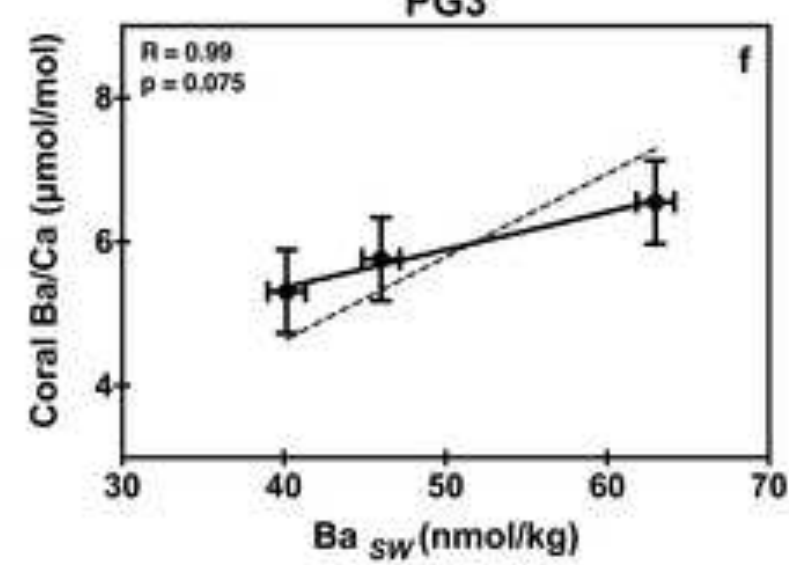

PC3

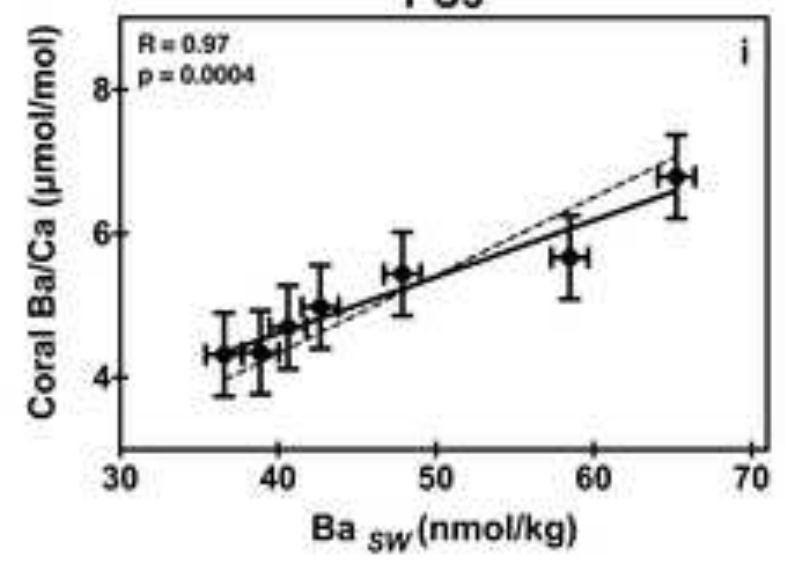



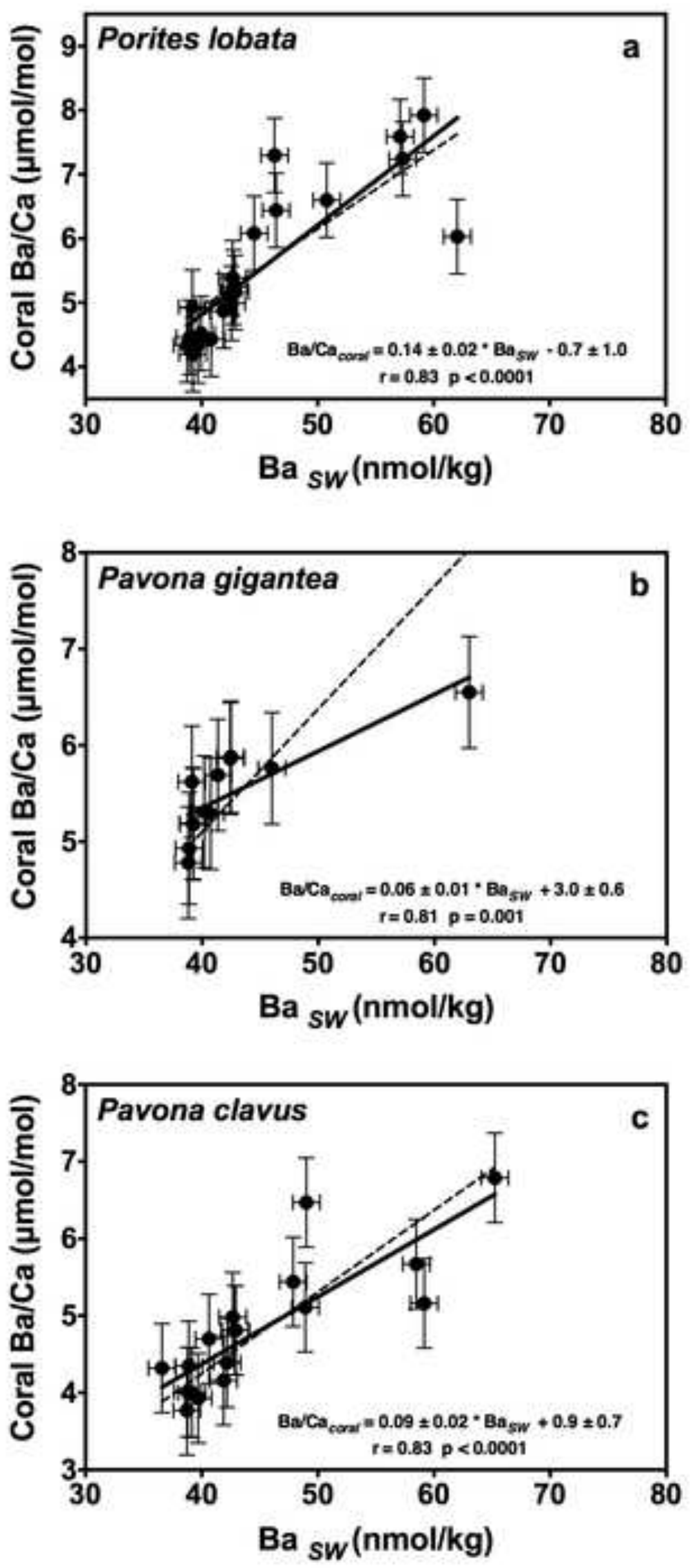

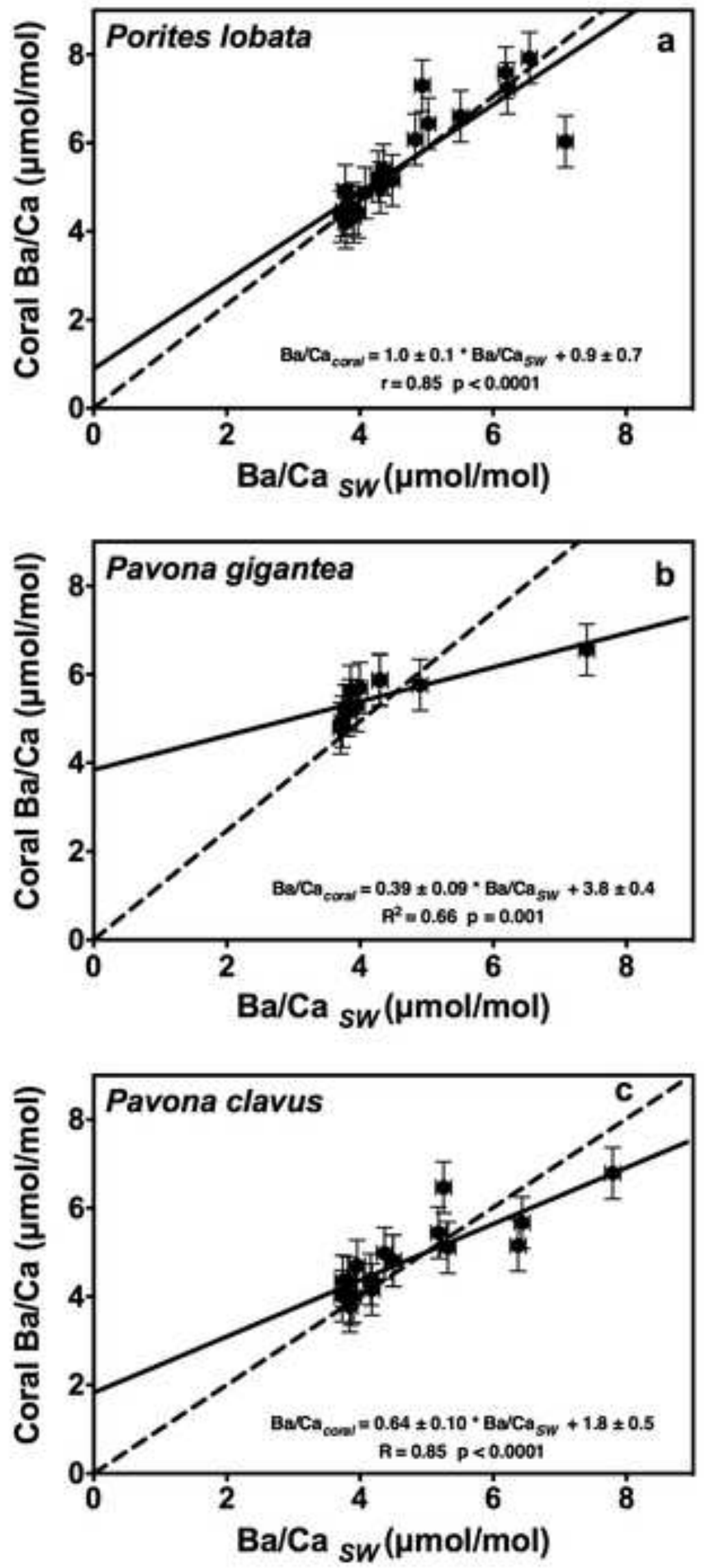


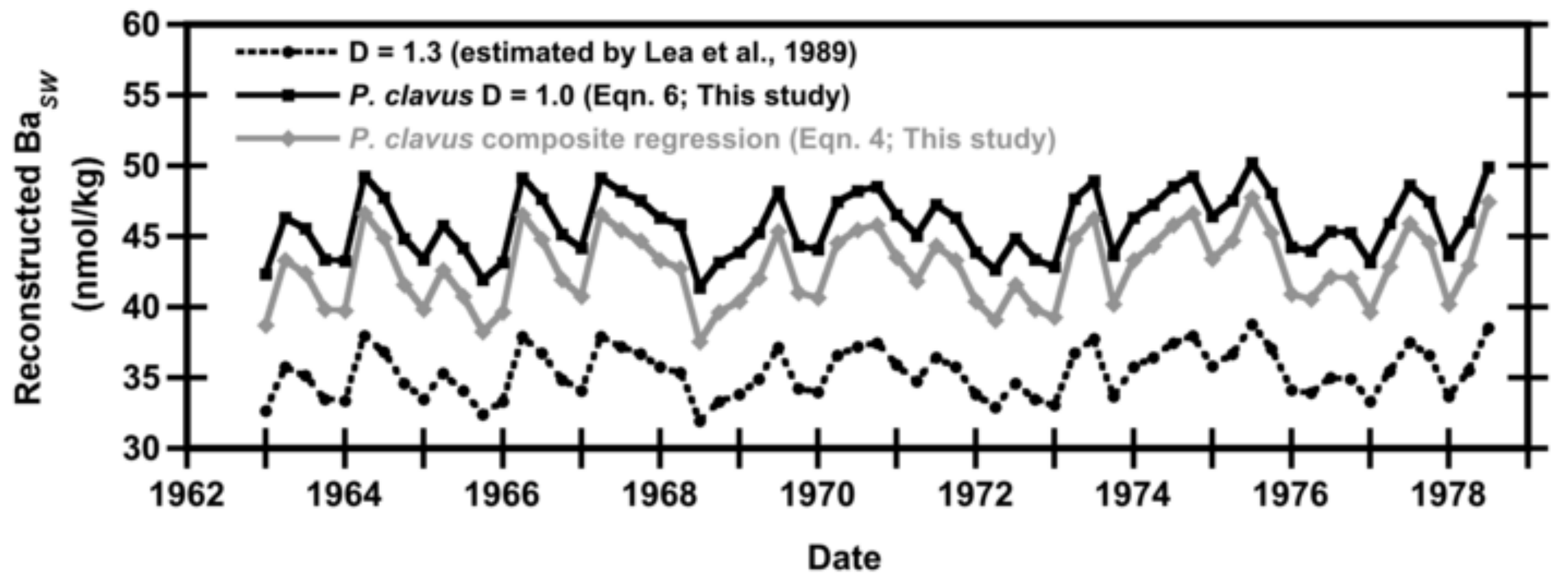

